\title{
CIDADE FLUTUANTE: UMA MANAUS SOBRE AS ÁGUAS
}

FLOATING CITY: A MANAUS ON THE WATERS

v. 8, n. 2 [13]

mai/ago (2016)
Leno Barata Souza

Universidade de Venezia - Ca`Foscari lenojbarata@ig.com.br

\section{Resumo}

Partindo da temática sobre a cidade, o artigo, fruto de pesquisa de doutorado, busca direcionar as discussões em direção à cidade flutuante de Manaus. Peculiar modelo de ocupação urbana sobre as águas da capital amazonense, a cidade flutuante nos serve de mote para refletir questões sobre cidade e cultura urbana na Amazônia, retomadas aqui, sobretudo por intermédio da história oral na forma de entrevistas com antigos moradores do lugar.

\section{Palavras-chave}

Cidade. Cultura Urbana. História Oral.

\section{Abstract}

From a theme, city, the article, result of doctoral research, intends to steer discussions toward the floating city of Manaus. Special model urban settlement on the waters of Manaus, the floating city serves as a motto to reflect questions about the city and urban culture in the Amazonia, reproduced here, mainly through oral history in the form of interviews with former residents of the place.

\section{Keywords}

City. Urban Culture. Oral History. 


\section{Cidade é isso!}

Tema espinhoso que historiadores, sociólogos, geógrafos e outros cientistas sociais têm enfrentado nos últimos anos são as questões sobre cidades e cultura urbana. Longe de querermos esgotar o intrigante assunto, mas reconhecendo que ele sempre tangenciou nossos estudos, decidimos confrontar, nos limites desse artigo, algumas de nossas ideias com as de outros estudiosos. Menos do que a busca de conceitos, o que nos move é o abrasamento das inquietações.

Fazendo um exercício de imaginação, as imagens urbanas que costumam vir à mente espelham os gigantes de aço, vidro, luz, néon e impessoalidade. As cidades, como um polvo sempre voraz que a tudo engloba, atingem inexoravelmente a tudo e a todos. Onipresente, ela está aberta a todos os rumos; narcisista, cotidianamente transforma seus espaços, reinventa lugares, põe à prova os encontros e, sobretudo, subjuga seus próprios horizontes.

Nas ideias sobre as cidades contemporâneas pode-se observar uma espécie de "epíteto do caos" que (LEFEBVRE, 1973, p. 104) animou nos seguintes termos: "as ciudades monstruosas, tentaculares, ciudades-moloc". Tal perspectiva é também tributária de um mundo global conectado as "nets" multimídias que cotidianamente "bombardeiam" nossos sentidos (MOURA e ULTRAMARI, 1996, p. 07), acabando por cristalizar cenários urbanos estereotipados como Nova York, Tóquio, Hong Kong, São Paulo, adestrando, enfim, as ideias às formas de uma cidade modelo.

Todavia, ao elevar o olhar para além dessas imagens consagradas pela mídia moderna, pode-se discutir o tema por intermédio de outras dimensões históricas. Quem sabe poderemos surpreender originalidades de outras formas urbanas e mesmo certa beleza que, de alguma maneira, possa suavizar o aspecto um tanto "carrancudo" da cidade de Lefebvre.

Não saberíamos precisar quando e nem porque as cidades foram inventadas e mesmo em obras fundamentais a questão não é esgotada. Pressupomos que a necessidade de proteção tenha sido o sentimento que, inicialmente, moveu alguns homens, em um determinado contexto histórico, a abandonar sua milenar vida errante para se agruparem em torno do propósito de aumentar suas chances de sobrevivência em um mundo que lhes era, via de regra, hostil e desfavorável.

Sentindo-se mais abrigado, o homem do neolítico pôde "filosofar" sobre si, os outros e os espaços onde pisava, agora um mundo de possibilidades sobre os quais começou a imprimir marcas próprias, signos culturais que vão das conhecidas pinturas rupestres em cavernas, aos primeiros colossos urbanos do "Mundo Antigo", no Nilo egípcio e no crescente fértil mesopotâmio.

Assim, o espaço gradativamente foi deixando de ser apenas local de passagem, para se enraizar como paisagem social, lugar prenhe de culturas diversas, realização do desejo humano por proteção e espaço melhor para viver e trabalhar. 
É admissível que, por esses vieses, as cidades possam representar o encontro entre um tempo politizado, carregado de disputas e crenças, e o espaço/lugar, outro "punto central" das ideias de Lefebvre (1973, 221, grifo nosso):

\footnotetext{
Hay un punto central resultado de nuestros análisis: la relación entre espacio y tiempo. Para mí, su importancia es extrema. Se trata de llegar a encontrar la relación entre el espacio y el tiempo según la idea general, o si se prefiere el principio de análisis, de que todo espacio social es un empleo del tiempo. El espacio es la manifestación de un empleo del tiempo en una determinada sociedad.
}

Acreditamos que as cidades possam também responder a duas questões de Milton Santos. Primeira: "Como ultrapassar o enunciado gratuito de um tempo unido ao espaço, mediante a relativização de um e de outro?" Segunda: "Como traduzir em categorias analíticas essa mistura que faz com que o espaço seja também o tempo e vice-versa?". Santos, tentando encontrar os elos dessa corrente, comenta: "[...] o ponto de partida é a sociedade humana em processo $[\ldots]$ ", que só aconteceria "[...] sobre uma base material: o espaço e seu uso; o tempo e seu uso; a materialidade e suas diversas formas; as ações e suas diversas feições", o espaço, para Santos, "[...] não existe sem a materialidade" (SANTOS, 2006, p. 50 e 54).

As cidades, de certo, não são a única ligação capaz de unir/interagir tempo e espaço, mas, sem dúvida, é o mais significativo elo que pode vincular a "base material" aos usos do tempo com suas "diversas formas e feições" que, segundo Antonio Augusto Arantes, longe de ser um mosaico de vidas inertes e separadas, se anima por intermédio de um palimpsesto social reescrito cotidianamente que, segue Arantes (2000, p.161, grifo nosso): "É hoje o sítio onde ganham configuração concreta experiências que ao mesmo tempo formam referenciais espaço-temporais flexíveis e identidades em processos de constante reconfiguração".

Elas passaram a ser o principal lugar onde as pessoas puderam experenciar a condição de moradores, vizinhos, inaugurando um sentido de comunidade, um sentimento de pertencer política e culturalmente a uma mesma coletividade que se vivifica também como um lugar de construção de histórias e memórias.

Nesses termos, o que anima a trajetória histórica das cidades é uma multiplicidade de formas cartesianas e tortas, que mesmo campos multidisciplinares do conhecimento não conseguiram apreender. Ainda assim, sobretudo nas últimas décadas, as cidades vêm motivando uma série de tentativas de classificá-las, ordená-las, mensurá-las e mesmo, como discutia uma sociologia dos anos sessenta e setenta, de lhes instituir "personalidades urbanas" diferenciadas: pacata, agitada, violenta, tranquila (LEDRUT, 1971, p. 168-173). A cidade foi posta no "divã" de onde não desceu mais, tamanhas suas incuráveis psicoses.

O intrincado enredamento das tramas urbanas acaba por fragilizar ou limitar as tipologias propostas sobre cidades que, em regra, se mostram fugidias e inteligíveis apenas a espaços próprios e sociedades específicas, acabando por "implodir" com qualquer sistema geral proposto. Como propõe Munford (1998, p. 09): "Não há definição que se aplique sozinha a 
todas as suas manifestações nem descrição isolada que cubra todas as suas transformações, desde o núcleo social embrionário até as complexas formas de sua maturidade e a desintegração corporal da sua velhice".

Raymond Williams (1989, p. 11-12) também negou a relação identitária entre as cidades, preferindo enfatizar os caminhos insuspeitos, tortuosos, intempestivos, mas, sobretudo diferenciados trilhados por cada uma delas, restando-Ihes em comum, como uma espécie de "DNA" urbano que as uniria, tão somente o nome "cidade".

Por outro lado, não seria o nome a construção social que confere os primeiros significados de uma identidade, seja ela qual for? Assim, ele carrega uma força histórica significativa que deve ser considerada para além de sistemas, conceitos e senso comum, que por aprisionar as ideias a uma camisa de força, inibem os debates e anestesiam as reflexões (WILLIAMS, 1979, p. 17-76).

Os conceitos são apenas a ponta de uma lança, cuja trajetória, densa e sinuosa, indica mais uma questão do que uma definição que, como propõe Marcel Roncayolo (1986, p. 396): "trata-se, pois, duma forma que admite conteúdos variáveis", entre os quais, apresentamos agora a "cidade flutuante" de Manaus.

\section{A cidade dos flutuantes}

A "cidade flutuante" representou um modelo de ocupação dos espaços fluviais que se avolumou em Manaus a partir do final da década de cinquenta quando vários dos sentidos culturais próprios de uma cidade vão começar a ser experenciados sobre as águas urbanas da cidade, nomeadamente na orla-sul do Rio Negro, Centro, "frente da cidade" e nos igarapés que, do rio, sobem Manaus adentro.

Entre esses significados, sobressaem o adensamento de casas flutuantes, o aumento populacional e a dinamização comercial, que além de reconfigurarem o lugar, passam a determinar novas formas de sociabilidades arraigadas a um cotidiano próprio, com uma estrutura de prestação de serviços, atividades comerciais, industriais e culturais ligadas a Manaus em terra e ao interior do estado, dando formas a uma rede urbana próxima às de outras realidades urbanas como as "cidades locais" de Milton Santos, cujas reflexões, de meados dos anos sessenta, tanto ofereceram um contraponto às nossas discussões sobre a "cidade flutuante" de Manaus, como iluminaram a conjuntura histórico no qual ela se desenvolveu.

A teoria de Milton Santos, se diretamente não contemplou a "cidade flutuante", permite observar os traços qualitativos que, como destaca o autor, são os mais importantes para os estudos das "cidades locais", e que se mostram próximos aos pensados para o contexto manauense: "Poderíamos então definir a cidade local como a aglomeração capaz de responder as necessidades vitais mínimas, reais ou criadas, de toda uma população, função esta que implica uma vida de relações" (SANTOS, 1982, p.71).

(c) Urbana: Rev. Eletrônica Cent. Interdiscip. Estud. Cid $\quad$ Campinas (SP) $\quad$ v.8, n.2 [13] $\quad$ p.115-146 ISSN 1982-0569 
Próxima às reflexões de Santos é a opinião do estudioso amazonense Arthur Cezar Ferreira Reis, que entre 1964 e 1967 também foi governador do Amazonas e principal líder da destruição da "cidade flutuante" e que pensa nos seguintes termos:

\begin{abstract}
A "cidade flutuante", ao contrário das aglomerações urbanas marginais de outras capitais do país, possui uma vida própria, com atividades econômicas de toda ordem, inclusive com prestações de serviços em geral, características as atividades citadinas, além de parte acentuada de habitantes colaborarem na vida do porto (REIS, 1965, p. 86).
\end{abstract}

Todavia, apesar de algumas cumplicidades teóricas, a "cidade flutuante" de Manaus tinha particularidades próprias que escapavam às características das "cidades locais". Uma das mais significativas diz respeito à localização. Se as "cidades locais sempre se acham na periferia do sistema urbano" (SANTOS, 1982, p. 74) a "cidade flutuante", pelo contrário, nasceu e floresceu em plena área central da capital amazonense e não em terra, mas sobre as águas.

Fenômeno urbano e social, a "cidade flutuante", apesar de sua contemporaneidade, continua marcada pelo esquecimento ou envolta em dúvidas e reticências, atravessando o século passado como um território historiográfico de silêncios. Quando das pesquisas, sempre nos surpreendeu a "invisibilidade" histórica das mais de 2 mil casas flutuantes com seus 12 mil moradores! É esta conjuntura, de poucas linhas e muitos silêncios, o território historiográfico da "cidade flutuante".

Por vezes, analisando uma documentação impressa a partir dos anos 20, tínhamos a nítida sensação de procurar por uma "cidade fantasma" que começou a ganhar vida apenas quando recorremos às narrativas orais de antigos moradores de Manaus, cujas lembranças nos levaram a outros confins da região, "esticando" o espaço de estudo de modo a entrever a cultura dos flutuantes em outras águas terminando por redimensionar os próprios limites de Manaus que se mostraram diferentes da atual cidade que se projetava sobre outras fronteiras.

De um universo de 14 entrevistados, 09 são originários das ribeiras interioranas amazonenses. ${ }^{1}$ Mapear suas origens nos ajudou a delinear os limites de uma Manaus que se mostrou bem diferente das dimensões territoriais da atual capital, com seus $11.408 \mathrm{Km}^{2}$. Se recuperarmos os alcances de 1938, por exemplo, surpreenderemos uma cidade de $84.569 \mathrm{Km}^{2}$ (INTERVENTORIA FEDERAL, 1942. p.13), ${ }^{2}$ quase oito vezes o território atual, assumindo

\footnotetext{
${ }^{1}$ Para evitar repetições, sublinhamos que todas as entrevistas foram feitas pelo autor, em Manaus, entre os anos de 2005 e 2009. Ao final do artigo, arrolei detalhadamente os entrevistados. Afora quando comprometa as compreensões, mantivemos a pronúncia dos entrevistados nas transcrições citadas.

2 Estudo quinquenal (1937-1941) que organizou Manaus em 03 distritos e 13 Zonas Distritais. Em 1955, tanto Careiro como Airão são desmembrados de Manaus passando a condição de municípios autônomos. As separações, no entanto, continuaram de difícil assimilação para os moradores acostumados com as relações sociais, culturais, econômicas e política/administrativa que os ligavam a Manaus. Assim, ao longo dos nossos estudos (1920-1967), a Manaus que narramos comporta estes limites.
}

(c) Urbana: Rev. Eletrônica Cent. Interdiscip. Estud. Cid Campinas (SP) V.8, n.2 [13] $\quad$ p.115-146 ISSN 1982-0569 
contornos de uma grande região que se projetava tanto de um lado, quanto de outro do Rio Solimões/Amazonas.

Até o início da década de 1940, a malha urbana de Manaus não havia sofrido mudanças significativas. Além do Centro, berço de sua origem, tinha grosso modo os bairros dos Educandos e Cachoeirinha à Leste, Mocó/Vila Municipal ao Norte e à Oeste, São Raimundo. Nos anos seguintes, no entanto, aconteceria o que Benchimol (1977, p. 360) chamou de "[...] o começo da explosão urbana na Amazônia".

A pressão de novas necessidades e demandas sociais propiciadas pelas imigrações dos anos quarenta, fruto da Segunda Batalha da Borracha e da Grande Enchente de 1953,3 fez-se sentir em todos os limites da cidade, estendidos sobre os terrenos de florestas ao Norte, ampliando antigos subúrbios e/ou criando outros, seguindo os cursos hídricos dos terrenos marginais ao Sul, na forma de palafitas e tapiris, e sobre as águas com moradias flutuantes.

Se até 1947, fim da "Batalha", existiam em Manaus aqueles quatro bairros, nos vinte anos seguintes, mais de onze novos seriam criados e/ou oficializados pelos poderes públicos. As pistas mais salientes dessa expansão, outra vez, nos levam as fronteiras líquidas da cidade. Nesse caso, e à passos largos, vamos segui-las.

Em 1947, sobre as terras do Mocó, um grupo de paraibanos iniciou o bairro de Nossa Senhora das Graças, incorporando-o nos anos seguintes. No mesmo ano, nas cercanias do Igarapé da Cachoeirinha, carvoeiros que ali trabalhavam no fabrico do carvão, para morar próximo à fonte dos seus serviços, fixaram residências, fundando o bairro de São Francisco.

Em 1950, um contingente chegado dos interiores amazônicos e do Nordeste brasileiro, ultrapassou o bairro dos Educandos criando São Lázaro e Crespo. No ano seguinte, nas imediações do Igarapé do Pancada, um lugar conhecido por Emboca é desmembrado do bairro dos Educandos e oficializado como bairro de Santa Luzia. Ao Norte do bairro de São Francisco, também em 1951, inaugura-se Petrópolis, e na outra frente de Manaus, limites do bairro de São Raimundo, a constante movimentação dos recém-chegados empurrou as fronteiras da cidade, resultando na criação de mais dois bairros: Santo Antonio e São Jorge (CODEAMA, 1966, p. 04).

Todos esses novos núcleos urbanos teriam ainda sua população subitamente acrescida pelas consequências da descomunal enchente de 1953, reforçando o trânsito de centenas de interioranos em direção à Manaus, que tanto potencializaram a demografia dos novos subúrbios, como criaram outros, exemplo do bairro da Glória, próximo a Santo Antonio e São Raimundo, fruto direto da grande alagação.

Tentando racionalizar e compreender esse avanço urbano, a Lei $n^{\circ} 367$, de 1951, promoveu um novo zoneamento de Manaus, segundo o mapa abaixo:

\footnotetext{
3 Segunda Batalha da Borracha: esforço brasileiro na Segunda Guerra no qual o Amazonas contribuiu com borracha silvestre, encerrado oficialmente em 1947.
}

(c) Urbana: Rev. Eletrônica Cent. Interdiscip. Estud. Cid Campinas (SP) V.8, n.2 [13] $\quad$ p.115-146 ISSN 1982-0569 


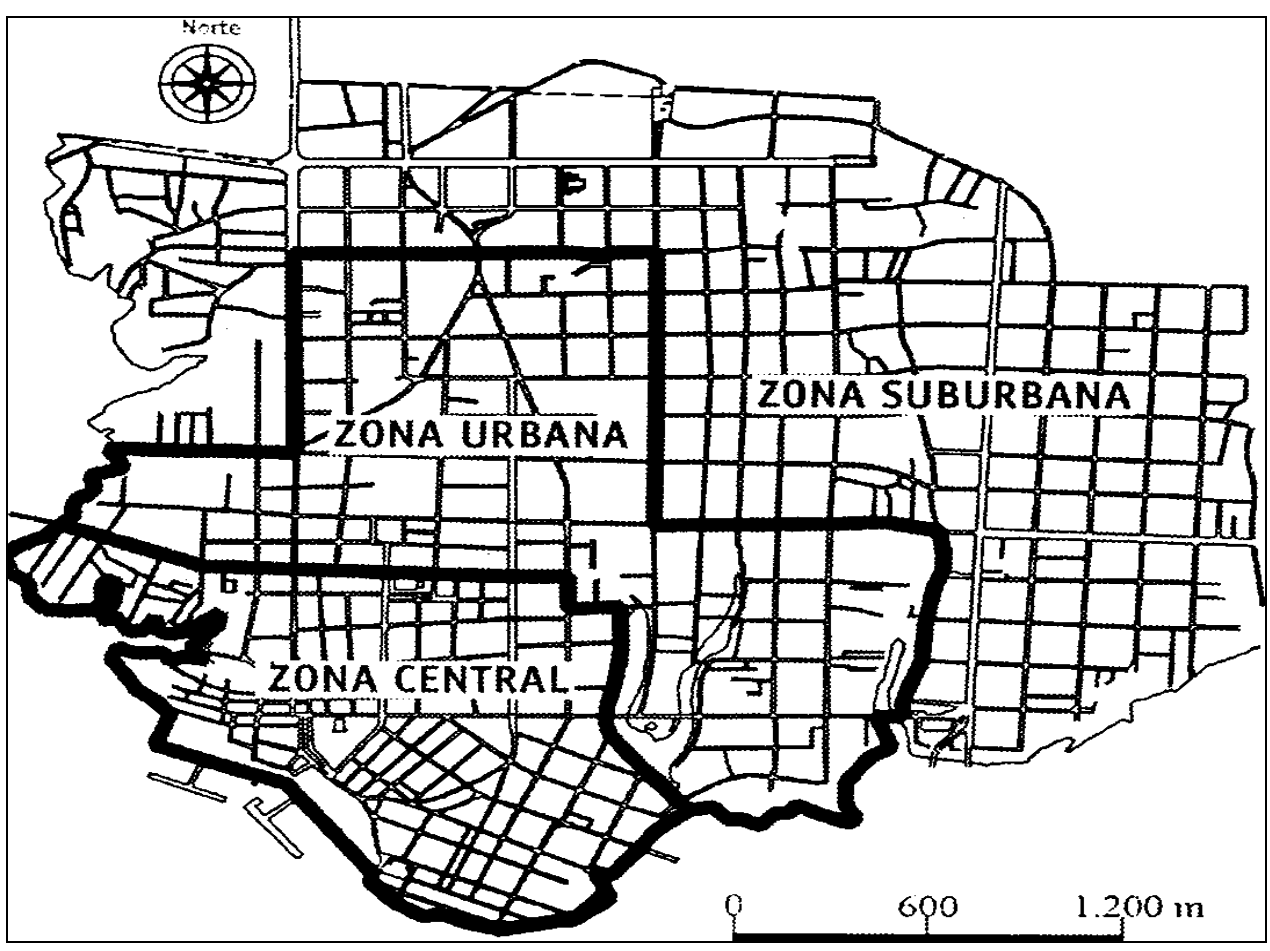

Figura 1: Planta do Zoneamento de Manaus, 1951. Fonte: (OLIVEIRA, 2003, p. 94.).

O Cadastro Predial de Manaus de 1952 atribuía para a capital um total de 10.358 casas, das quais mais da metade, exatamente $55,1 \%$, perfilavam-se entre os conhecidos modelos de habitações populares: casebres, estâncias, barracões e casas de taipa ou de madeira (Apud Oliveira, 2003, p. 77), que as Posturas Municipais toleravam apenas na área suburbana e rural, ou seja, bairros, vilas e distritos longe do Centro.

No mesmo período, o sociólogo André de Araújo percorreu um total de 1990 casas da capital, quase $20 \%$ do universo do Cadastro Predial, chegando à conclusão de um presente "problemático" e de um futuro nada promissor:

Com exceção de um número muito pequeno, os tipos de casas são os mais pobres possíveis. Domina em todos, verdadeiramente, o tipo mocambo coberto de palha, de zinco ou de telha, fechado de palha, de madeira ou te taipa. A capital esta cheia de casebres, de casinhas fora das condições higiênicas. É nesse meio onde a infância e adolescência crescem sem condições de vida próprias para vencer amanhã (ARAÚJO, 2003, p. 329).

Chama atenção no inquérito de Araújo "a influência da água" como fator poderoso para as escolhas dos espaços de moradia e para o futuro habitacional problemático da cidade pensado pelo autor. Do total de 1990 habitações, 1321 estavam "perto de charcos, igarapés, rios, alagadiços" e outras 62, "invadidas pelas águas"; o restante, 607, "em altos ou colinas". Somando-se o primeiro e o segundo dado, chegaremos a 1383 habitações, quase $70 \%$ das moradias, extremamente íntimas ao extenso circuito fluvial que margeia e entrecorta Manaus, ou, como sintetizou o próprio pesquisador: "a água domina isso tudo" (Ibid., p.341). 


\section{As águas da cidade}

Mais especificamente, tudo o quê? Quais eram os seus domínios? Que águas eram essas? Quais eram dominadas pela "cidade flutuante"? Inicialmente, as questões nos remeteram as "rias", neologismo (rios + ruas) do geógrafo francês Pierre Gourou, cujos argumentos o autor também expressou em imagens como o mapa a seguir:

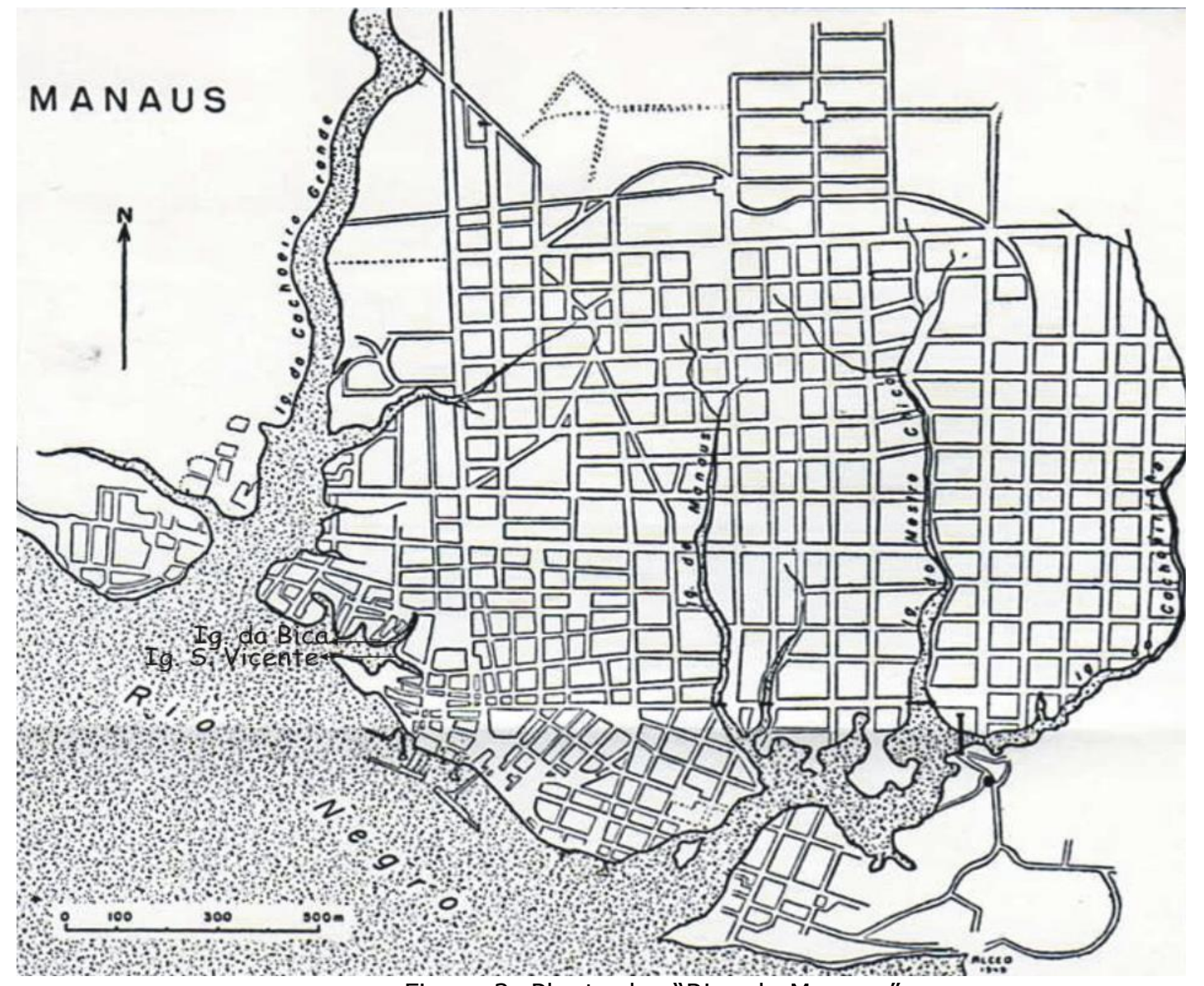

Figura 2: Planta das "Rias de Manaus".

Fonte: Revista Brasileira de Geografia, jul-set. 1949, p. 393.

Pierre Gourou identificou apenas as cinco principais "rias" de Manaus: Igarapé da Cachoeira Grande (ou São Raimundo), Igarapé de Manaus, Igarapé do Mestre Chico, Igarapé da Cachoeirinha (ou Educandos) e a maior de todas as "rias", o Rio Negro. ${ }^{4}$ A cartografia do autor visava os grandes cursos fluviais de Manaus, eram eles que justificavam e animavam as suas "rias" e não a infinidade de subafluentes que se perdiam (e ainda se perdem) Manaus adentro, propiciando os mais diferentes nomes e limites para um mesmo curso de água, dúvidas que também se estenderam aos livros e aos levantamentos e mapas oficiais desde sempre.

4 Igarapés da Bica e São Vicente são interferências nossas no mapa de Gourou; informamos que o Igarapé de Manaus também é chamado de Bitencourt, nome de uma de suas ramificações, acima e a direita, que o Mestre Chico e Cachoeirinha começam como Igarapé do Quarenta na boca com o Rio Negro.

(c) Urbana: Rev. Eletrônica Cent. Interdiscip. Estud. Cid Campinas (SP) v.8, n.2 [13] $\quad$ p.115-146 ISSN 1982-0569 
Se o leito das águas é o berço de nascimento costumeiramente lembrado, elas também costumam balizar fronteiras, ou ainda serem rebatizadas pelos moradores da área. Ainda hoje, em Manaus, vários bairros, sobretudo os mais antigos (São Raimundo, Educandos e Cachoeirinha) confundem-se com seus igarapés.

O Igarapé do Quarenta, à medida que os bairros foram sendo abertos na década de cinquenta, foi sendo renomeado como Santa Luzia e Crespo. Mais acima, o Igarapé da Cachoeira também passou a ser chamado de São Francisco ou Petrópolis, em referência aos bairros recém-criados. No Igarapé de São Raimundo, margem do bairro, várias de suas artérias foram, dependendo do novo bairro, sendo rebatizadas: Glória, Santo Antonio e São Jorge.

Todo esse complexo de águas que o mapa de Gourou somente "arranha", e de nossa parte apenas ensaiamos, mostra-se, em maior plenitude, por intermédio de outro mapa que detalha a rede de drenagem da cidade, enfocando e mensurando as três bacias dos igarapés que cortam Manaus: São Raimundo, Central e Educandos.

Como toda cartografia hídrica na Amazônia, essa também não é unânime e várias outras contestam seus limites, dimensões e nomes. A Bacia Central, por exemplo, devido à quase completa aterragem dos seus igarapés, ${ }^{5}$ para alguns estudiosos, nem pode mais ser apresentada como uma bacia hidrográfica. No entanto, no Centro de Manaus, o Rio Negro é mais do que suficiente para Ihe garantir essa condição hidrográfica, levando outros especialistas a chamá-la de Bacia do Negro.

De qualquer forma, decidimos pelo mapa abaixo que tanto potencializa o mapa de Gourou, como esgarça as linhas do nosso ensaio, destrinchando e aprofundando mais os caminhos das águas, território sobre o qual Manaus avançava tanto na forma de novos bairros cidade acima, em terra, como por intermédio de flutuantes na orla Sul, a partir das águas do Rio Negro:

${ }^{5}$ Igarapés do Espírito Santo e Aterro sobre os quais correm hoje, respectivamente, as avenidas Eduardo Ribeiro e Getulio Vargas. Os aterros dos igarapés manauenses seguem com todo vigor nos dias atuais, assim se resolve, para os políticos, as questões de mobilidade urbana e saúde pública. Os aterros não passam de enterros, sepultamentos de antigos cursos fluviais que hoje jazem sob o asfalto.

(c) Urbana: Rev. Eletrônica Cent. Interdiscip. Estud. Cid Campinas (SP) V.8, n.2 [13] $\quad$ p.115-146 ISSN 1982-0569 


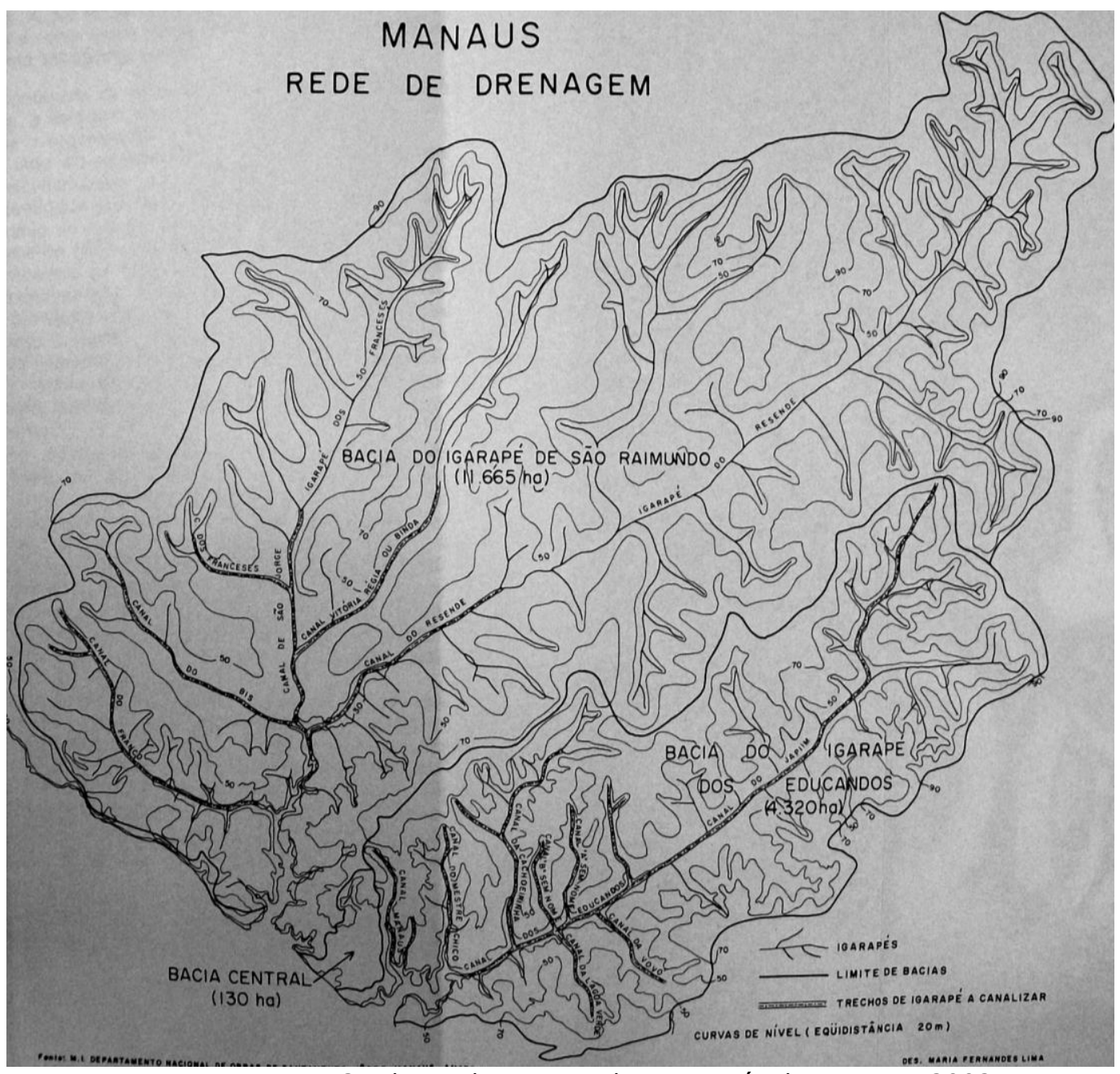

Figura 3: Planta das Bacias dos Igarapés de Manaus, 2002.

Fonte: Departamento Nacional de Obras de Saneamento - Manaus.

As três bacias juntas somam $161,15 \mathrm{~km}^{2}$. Levando-se em conta que o perímetro urbano de Manaus tem um total de 229, $5040 \mathrm{~km}^{2}$, pode-se mensurar o alcance dos domínios das águas fluviais na cidade de Manaus. A bacia de São Raimundo é a maior, destacando-se os igarapés do Mindu, Binda, Franceses e Franco. A Bacia do Educandos, por sua vez, possui mais e maiores corredores de água, salientando-se os igarapés de Manaus, Quarenta, Mestre Chico e Cachoeirinha. Finalmente, a maior de todas, a Bacia do Negro, cujo rio, considerado apenas entre os bairros de São Raimundo e Educandos, perfaz uma costa de mais de $15 \mathrm{~km}$.

Os domínios da "cidade flutuante" se faziam sentir com mais proeminência nesse intervalo de águas do Rio Negro e sua foz com as bacias de São Raimundo e Educandos. Decerto um domínio desigual, esparso em São Raimundo, inexistente próximo ao Porto de Manaus e extremamente adensado nas águas do Centro (chamada "Amazonense") e no Porto de Catraia dos Educandos. De uma forma ou de outra, a "cidade flutuante" ocupou todas as três bacias hidrográficas de Manaus. 
Então, é hora de adentrarmos nesses rumos, no sentido sul da expansão urbana manauense, notadamente em suas longas e intrincadas margens fluviais à costa e serpenteando o interior da capital, território da Manaus sobre as águas.

Estudos demográficos sobre a "cidade flutuante" só foram verificados a partir de 1960, quando algumas pesquisas encomendadas pelo governo do Amazonas procuraram por referências estatísticas sobre o lugar. O que prevalecia era a pouca atenção das autoridades, que como informa o primeiro desses levantamentos, nunca tiveram nenhuma "[...] ideia da quantidade nem da época em que surgiram os flutuantes em Manaus" (SERRA e CRUZ, 1964, p. 21). Se até meados dos anos cinquenta eram diminutos e dispersos, posteriormente foram assumindo grandes dimensões territoriais e demográficas, cujos significados começaram a codificar a construção do próprio termo "cidade flutuante": um complexo urbano, segundo os estudiosos, uma problemática social para as autoridades, um lugar para se viver, segundo seus moradores.

Apesar da escassez dos dados, consegui levantar três estatísticas oficiais sobre a "cidade flutuante", cujos dados organizei no quadro a seguir:

\begin{tabular}{|l|l|l|}
\hline Ano & Flutuantes & \multicolumn{1}{|c|}{ Moradores } \\
\hline 1961 & 1.389 & - \\
\hline 1964 & 2.145 & 9.788 \\
\hline 1966 & 1.950 & 11.400 \\
\hline
\end{tabular}

Quadro I: Censo da Cidade Flutuante.

Fonte: dados de 1961, (Apud Salazar, 1985, p. 77); dados de 1964 (Serra e Cruz, 1964, p. 37 e 41); dados de 1966, (Lenz, et al., 1966, p. 07).

Infelizmente, Gilberto Mestrinho precisou apenas o número de casas flutuantes para 1961 , as quais, em apenas três anos, sofreram um aumento de mais de 35\%, ou 756 novos flutuantes sobre as águas de Manaus. Se em 1966 a diminuição do número de casas já era um reflexo do processo de destruição da "cidade flutuante", o pequeno decréscimo das moradias é compensado pelo aumento, em menos de dois anos, de $14 \%$ de novos flutuantinos.

Nas conversas com os moradores do lugar, ainda pudemos recuperar particulares projeções estatísticas que também deram a conhecer fronteiras e demografias da cidade sobre as águas. Mário dos Santos estimou para a "cidade flutuante" "[...] uma população aí de seus 20 poucas mil pessoas [...]", números não muito distantes dos oficialmente levantados. É preciso considerar que Mário, ao contrário da maioria dos entrevistados, além de uma formação acadêmica (psicólogo), sempre foi um grande curioso dos assuntos amazônicos. ${ }^{6}$

\footnotetext{
${ }^{6} \mathrm{Na}$ época, Mário também estava procurando informações sobre flutuantes, fomos juntos a uma secretária de governo, onde não encontramos nada, e a Biblioteca Pública do Estado. É possível que Mário dos Santos também tenha lido as obras pioneiras sobre o assunto. Sua suposição estatística surgiu também quando conversávamos sobre a questão dos flutuantes de Manaus representarem ou não uma
}

(c) Urbana: Rev. Eletrônica Cent. Interdiscip. Estud. Cid Campinas (SP) V.8, n.2 [13] $\quad$ p.115-146 ISSN 1982-0569 
Situação semelhante à do arquiteto João Bosco Chamma, todavia, as semelhanças terminam nesse ponto. João Chamma, nascido em 1954, é doze anos mais novo que Mário e sempre fez questão de sublinhar que sua família faz parte da classe média dos tradicionais comerciantes sírio-libanesas de Manaus. Muito diferente, portanto, da vida levada pelo antigo canoeiro Mário dos Santos, para quem a "cidade flutuante", além de espaço de moradia, era ainda o território do seu ganha pão.

João Chamma também nunca foi morador de flutuante. Para ele e outros meninos de sua infância, a "cidade flutuante" significava apenas um grande parque a céu aberto. Ainda assim, ao longo da entrevista, ele, partindo de suas atuais experiências profissionais, deduziu que a "cidade flutuante" "chegou a ter 10.000 pessoas morando", outro dado, mais próximo ainda, aos levantamentos oficias.

Outros entrevistados, sem os mesmos refinamentos estatísticos de Mário e João, também fizeram interessantes projeções da "cidade". Creuza de Andrade dimensionou a "cidade flutuante" a partir do momento em que foi obrigada a deixá-la em 1966, contando que o processo de retirada das famílias, devido ao longo trecho de águas ocupadas, e ao contrário do que imaginávamos, foi longo e lento.

Para ela, as grandes extensões da cidade sobre as águas foram medidas pelo ritmo compassado da saída dos moradores, sobretudo dos seus muitos vizinhos na "Amazonense". Segundo suas lembranças: "[...] era muita gente, pelo amor de Deus! Era muita gente e tudo, nós fomos quase os últimos, da metade pra nós é que ficaram, nós saímos é assim".

Para Francisca da Silva e seu filho Francisco, Manaus se confundia com a "cidade flutuante", onde moraram por um breve período. Para ela, todos na capital "[...] moravam era na água mesmo, é tudo era no flutuante; tudo era água [...]", e para o seu filho, com quatorze anos à época, a cidade em que aportou o impressionou por ser toda flutuante, "[...] ighi! Era flutuante, a cidade era toda flutuante, não tinha casa palafita não, tudo era flutuante, tudo ali era flutuante naquela época $[\ldots]^{\prime \prime}$.

As hiperbólicas reconstruções de mãe e filho podem ser compreendidas se atentarmos à trajetória de suas vidas, nas quais a vizinhança com as águas sempre foi marca constante. Desde as ribeiras interioranas de Tefé, Coari, Copéa (cidades interioranas) e na própria Manaus, em 1962, eles sempre viveram pelas beiras urbanas e rurais: primeiro oito meses ancorados no Igarapé dos Educandos, depois nos flutuantes da "Amazonense", no Centro, em seguida a colônia agrícola no Igarapé do Tarumã e, finalmente, o flutuante alugado no Rio Negro.

Para Francisco e Francisca, Manaus sempre se projetou mais da margem para as águas do que da margem para a terra, que, segundo eles, ainda hoje representa um território que Ihes é pouco conhecido. Dos famosos símbolos urbanos da cidade, por exemplo, eles sempre

cidade, foi quando começou a falar sobre o conceito norte americano de urbe, algo também enfocado nos estudos de Serra e Cruz (1964, p. 26-27).

(c) Urbana: Rev. Eletrônica Cent. Interdiscip. Estud. Cid $\quad$ Campinas (SP) $\quad$ v.8, n.2 [13] $\quad$ p.115-146 ISSN 1982-0569 
destacaram o Mercado Central, vizinho à "cidade flutuante" e lugar dos serviços de Francisco e seus irmãos.

João Cesário, de sua casa e oficina de barcos nas margens do Igarapé dos Educandos, sempre andou muito por Manaus, tanto para fazer compras no Mercado, quanto por conta das burocracias de sua oficina junto à Capitania dos Portos. Quando lhe perguntamos sobre as dimensões da "cidade flutuante", ele a retoma também em meio a uma destas rotineiras andanças entre o bairro e o Centro, em cujo caminho os flutuantes, que não paravam de aumentar, foram se tornando uma paisagem e uma passagem obrigatórias, ambas medidas nos seguintes termos por João:

Mas isso, mas era só mais ali na frente da Igreja dos Remédios, naquela margem ali, ia aumentando assim lá pro meio do rio, porque nas partes laterais já não tinha mais pra onde botar, aí botando pro meio do rio, tanto que a gente andava, mais ou menos, assim, eu calculo assim uns 150 metros da beira até no último [flutuante], era muito grande, chegou a ter, mais ou menos, uns 850 flutuantes ali [na frente da Igreja dos Remédios]; fora os que estavam dentro dos igarapés, na margem do Rio Negro, ali pra baixo, porque nos igarapés tinha vários, tinha muitos flutuantes também [...].

Renato Chamma, a partir dos seus endereços comerciais na frente de Manaus, acompanhou de perto o crescimento da "cidade flutuante". Para dimensioná-la, ele retoma antigas imagens da capital, especialmente seus cartões postais. Um desses traz uma parte da "cidade flutuante", que como enfatizou Renato, com o postal em mãos: "[...] estas fotos aí é só a metade, tem o total não [...]". Ela transbordava as margens da imagem, tomando quase todas as águas do rio e igarapés de Manaus.

A seguir, o postal de Renato Chamma que conhecíamos e já o possuíamos. Mas que, sob as luzes de suas lembranças, a imagem ganhou novos focos e profundidades, cujas perspectivas iluminam fronteiras e formas da Manaus sobre as águas: 


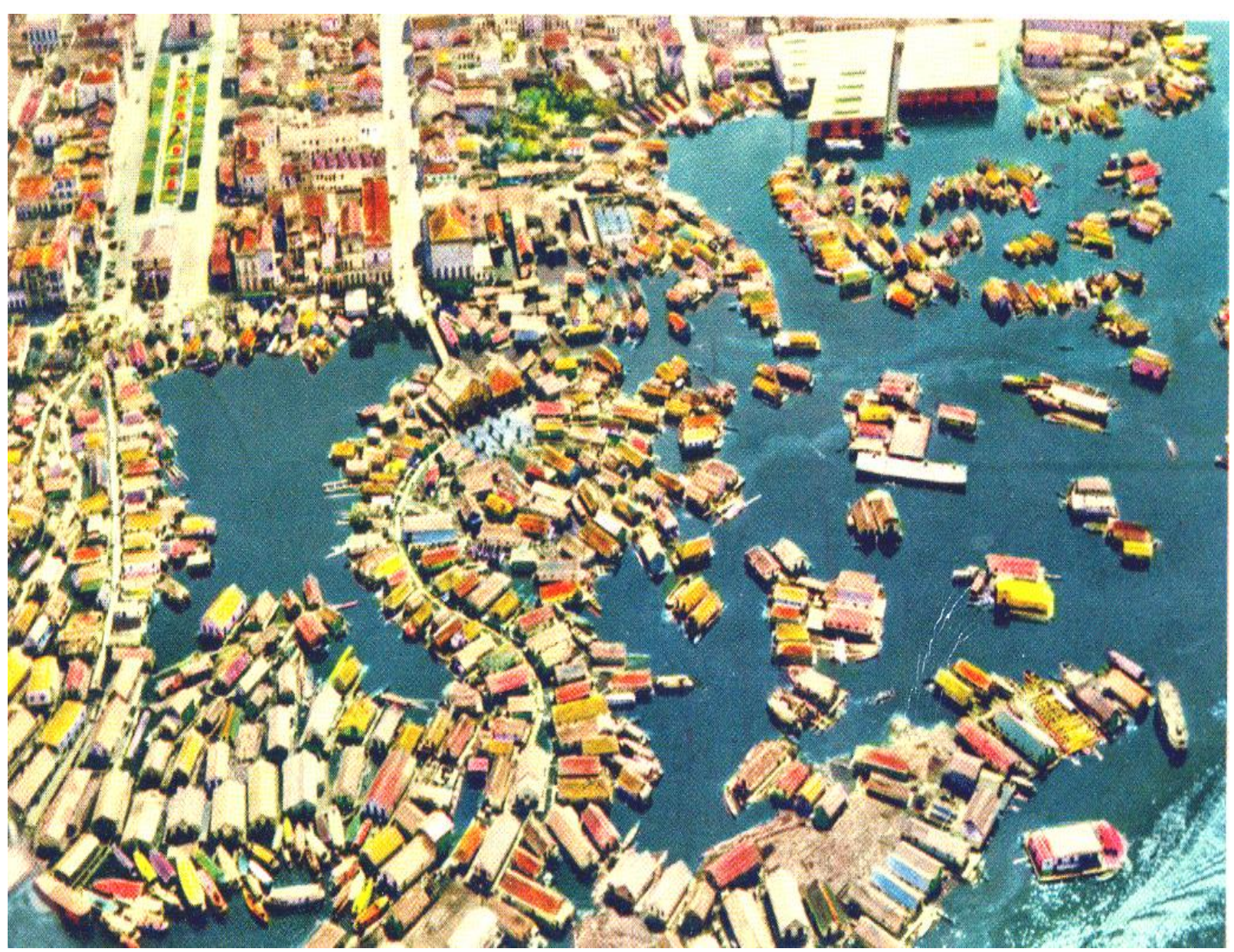

Figura 4: Postal de Manaus - Cidade Flutuante no Rio Negro, (circa 1964). Fonte: Arquivo Particular do Professor Dr. Otoni M. de Mesquita.

Francisca Malta partiu de seu flutuante, "[...] da praia da Amazonense $[\ldots]$ " e estendeu a "cidade" "[...] até perto da Serraria dos Pereira [...]", uma serraria flutuante nas águas dos Educandos. Desse ponto saiu Vivaldo Correa: "[...] era ali a cidade flutuante, começava do Educandos $[\ldots]$ ", passava pelo seu flutuante na "Amazonense", para "[...] terminar no São Raimundo né, no igarapé do São Raimundo [...]" formando um sinuoso percurso sempre traçado nas narrativas de Sebastião Garcia: "[...] olha essa frente aqui de Manaus, aqui era a cidade flutuante $[\ldots]^{\prime \prime}$.

Dessa vez, não tivemos dificuldade para entender as indicações de Sebastião. Bastou seguir o caminho de suas mãos e a direção de seus dedos apontados para fora de sua banca de pimenta na Feira do Produtor, Centro de Manaus, antiga "Amazonense", onde por três vezes o entrevistei. Estávamos no antigo território da cidade sobre as águas.

Outra via de compreensão dos territórios, caminhos, direções e dimensões reconstruídas pelas narrativas é o mapa a seguir, único encontrado da "cidade flutuante": 


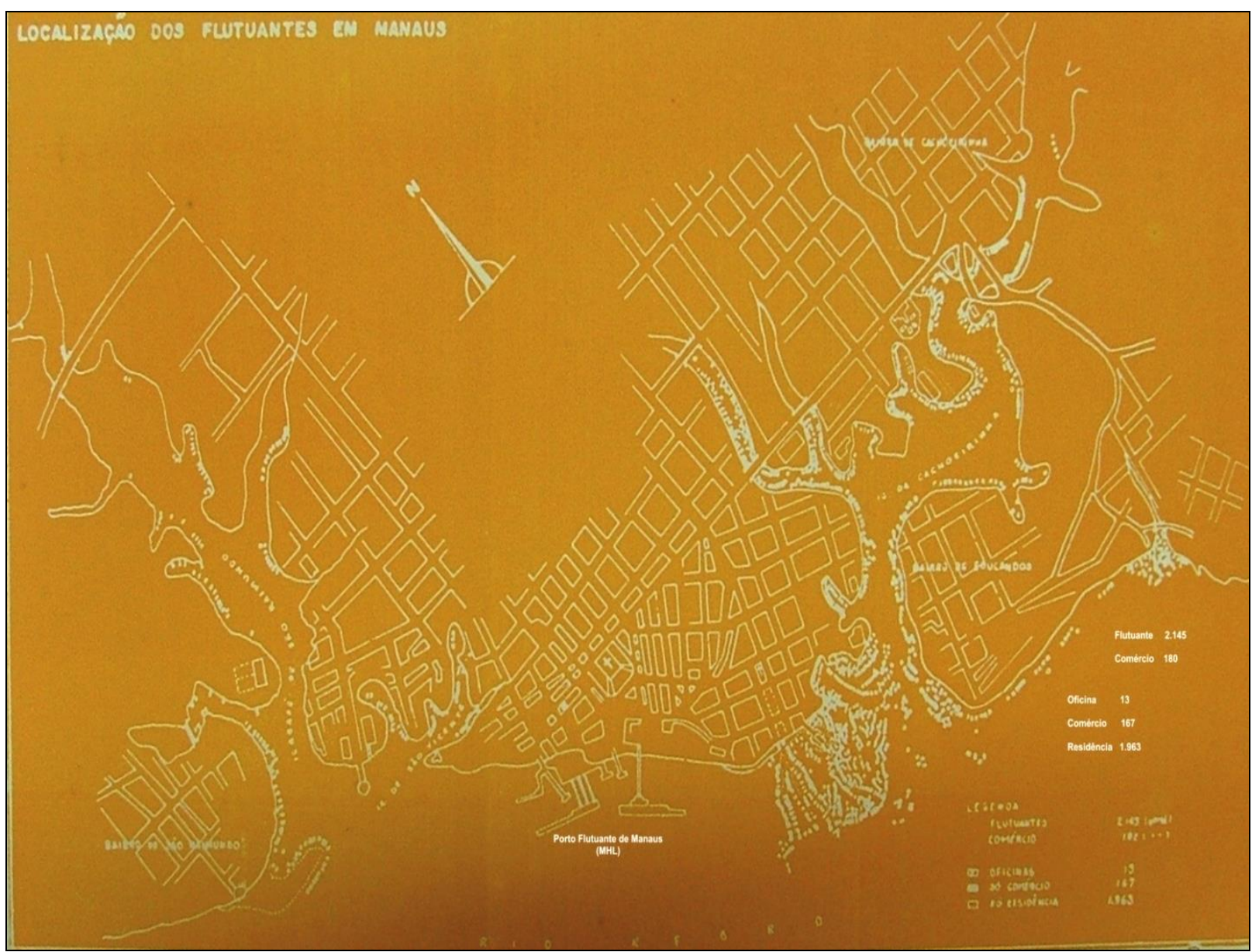

Figura 5: Planta da Localização dos Flutuantes de Manaus. Fonte: Serra e Cruz (1964, p. não numerada).

A "cidade flutuante", a partir do Rio Negro, não parava de avançar sobre as fronteiras líquidas de Manaus, sendo a parte mais impactante do boom urbano em marcha constante pela capital. Os limites naturais das águas do rio e igarapés foram sendo paulatinamente vencidos, ocupados e reterritorializados por uma crescente população que se valendo dos seus modos de vida e frente às novas necessidades e demandas da cidade grande, começaram tanto a conferir novas linhas e formas à malha urbana de Manaus, como a escreverem outras narrativas sobre a cidade.

Entre as muitas histórias, decidimos por problematizar as questões da construção das casas: como elas eram construídas?

\section{Os flutuantes da cidade}

Creuza de Andrade já estava casada quando foi morar sobre as águas do Rio Negro onde, em 1962, seu marido alugou um pequeno flutuante na "Amazonense". Ela não lembrou muito bem o valor do aluguel, era o marido "[...] que pagava tudinho", que resolvia tais assuntos, mas, segundo sua estimativa, não devia chegar a 20 cruzeiros, "[...] era baratinho [...]", ainda assim, mais do que os 15 cruzeiros recebidos por ele mensalmente como marítimo. Dessa forma, os vencimentos que Creuza conseguia, trabalhando em um 
restaurante flutuante ali perto, deveriam ser vitais para completar o aluguel e sustento da família acrescida pela chegada das filhas Ângela e Marcilene.

O flutuante de Creuza era um pequeno quarto/sala e cozinha em uma das muitas vilas flutuantes. Ela me contou que o quarto ficava de frente para a beira, e nos fundos ainda residiam outras duas famílias: "[...] três divisões dava naquela casa para cada pessoa, era a sala que fazia de quarto e a cozinha tipo um embriãozinho [...]", esboçou Creuza que ainda descreveu a cobertura de palha ordinária, que para ela dava ao flutuante a aparência de "vagabundinho", todo de madeira a começar pelos alicerces, as boias de sustentação/flutuação das casas: "assentadas em cima de toro de madeira né $[. .$.$] bem pregado no outro, era assim$ grudado $[\ldots]^{\prime \prime}$, concluiu as formas de sua antiga casa flutuante.

Francisco e Francisca da Silva, pouco tempo depois de Creuza, por volta de 1963/64, também foram morar na "Amazonense" em um flutuante alugado junto ao Cristóvão, parente de Coari que havia imigrado para Manaus há muitos anos e vivia na época, como narrou Francisco, exclusivamente da locação de pequenos quartos na "cidade flutuante". O aluguel girava em torno de 1 ou 2 mil cruzeiros, ou 1 cruzeiro pago diária, semanal ou mensalmente, dependendo dos acertos e acordos com o locador. Seja como for, o dinheiro do aluguel consumia parte das lavagens de roupa de Francisca e dos pequenos serviços de Francisco nos arredores Mercado Público.

Os flutuantes de Cristóvão também formavam uma vila de casas na "Amazonense", que segundo os cálculos de Francisco, tinha 7 metros de comprimento por 5 metros de largura. Um espaço mínimo ainda, "[...] dividido em três quartos, nós morava num quarto daqui pra cá, e outra família do quarto pra lá, era pequeno assim, uma área de 2 metro de largura por 3 de cumprimento".

As projeções de Francisco, à primeira vista, podem parecer meros cálculos aleatórios. Porém, coincidiram com os levantamentos técnicos das pesquisas de 1964 quando Serra e Cruz (1964, p.38) foram à "cidade flutuante" e com réguas e marcas levantaram as variadas dimensões das casas, um máximo de $4 \times 7 \mathrm{~m}^{2}$ e um mínimo de $2 \times 3 \mathrm{~m}^{2}$, justamente a dimensão que Francisco calculou para o seu flutuante.

O flutuante de Francisco, como informam suas narrativas, pouco se diferenciava do de Creuza. Ambos eram inquilinos em um pequeno quarto de uma vila de flutuante, casas de madeira, cobertas de palha e levantadas sobre troncos de árvores nas águas do Rio Negro, no Centro de Manaus. Formas estas que também se aplicam aos flutuantes de outros dois moradores da "Amazonense", Francisca Malta e Vivaldo Correa. No entanto, as semelhanças param aí, pois ambos, ao contrário de Creuza de Andrade e Francisca da Silva, eram proprietários de suas casas flutuantes.

Francisca Malta e seu marido, depois da reconciliação, compraram um flutuante em 1960. Ela, a exemplo de Creuza, não lembrou os valores acordados com seu marido, que depois de adquirir o flutuante, foi logo buscar a esposa e a filha Socorro, "[...] a minha casa,

(c) Urbana: Rev. Eletrônica Cent. Interdiscip. Estud. Cid Campinas (SP) V.8, n.2 [13] p.115-146 ISSN 1982-0569 
tinha uma sala, quarto e a cozinha e o corredor $[\ldots] "$, além da varanda com o portão sempre fechado, enfatizou Francisca, para manter os filhos longe das águas do rio. Seu flutuante devia ser um pouco maior que o "embriãozinho" onde morava Creuza, ou o "quarto pequeno" reconstruído por Francisco da Silva.

Vivaldo Correa e a mãe, ao chegarem do Rio Madeira, no início dos anos cinquenta, aproveitaram que "[...] o rio tava seco [...]" para levantar um tapiri na beira da "Amazonense". Em seguida, com o salário de padeiro e mais as lavagens de roupa da mãe, conseguiram economizar um dinheiro, cerca de "mil réis", calculou Vivaldo, e compraram ali mesmo uma "barraquinha" de chão, madeira e palha.

Com a cheia colossal de 1953, a saída foi transformar a barraca em flutuante. Vivaldo conseguiu as boias, "[...] aquelas toras de pau que fica $[\ldots]$ " em baixo do flutuante e eram, como sublinhou, "o principal" para se levantar o flutuante. Comprou mais madeira para cercar, aproveitou o material restante da "barraquinha" e suspendeu a casa sobre as toras de flutuação. Como o dinheiro era pouco, fechou as laterais com palha mesmo e estava pronta a casa: "era quarto, sala e cozinha, né".

Com o passar dos anos e os bons soldos, primeiro do Exército e depois da Polícia Militar, Vivaldo pôde ir "melhorando" a casa, um ajuste ali, a construção da varanda acolá, as palhas foram substituídas por madeira nas paredes, mas a cobertura, como na maior parte das casas dos seus vizinhos, permaneceu de palha mesmo. "[...] só quem cobria na cidade com telha de alumínio [...] era o pessoal bem abastardo [...]", comentou Vivaldo, e Francisco da Silva acrescentou: "[...] o alumínio era caro, não tinha condições né $[\ldots]$ ".

Se as telhas de alumínio começavam a representar uma diferenciação social entre os moradores da "cidade flutuante", as famílias de Sebastião Garcia e Edneia Cortezão estariam em posição de destaque? Deste modo, nos "dirigimos" aos seus flutuantes.

O flutuante do cunhado de Sebastião no Igarapé da Cachoeirinha, lembrou ele, era um "grande flutuante", coberto de alumínio, só ficando atrás da casa do próprio Sebastião, arrematada do seu vizinho e para a qual Sebastião não poupou elogios e saudades. O zinco cobria todo o flutuante, "75 palmo de casa!", mensurou Sebastião (perto de 16,5 m²), "[...] coisa maravilhosa! [...]". As boias, seguiu narrando, "[...] dessa altura aí [...]" (suspenso do chão há quase um metro), alto o suficiente para estacionar em baixo a canoa em que ele vinha do Mercado Central, cheia de pimentas e verduras para serem vendidas na feira do Mercado da Cachoeirinha.

Sebastião e eu conversávamos em sua atual barraca de pimentas na Feira do Produtor, Centro de Manaus, onde ele, aos moldes de Francisco da Silva, continuou não apenas reconstruindo, mas ainda teatralizando as formas de sua antiga casa nas águas da Cachoeirinha: "[...] metia, digamos, aqui era uma boia, aqui era outra, eu metia a carnaúba por debaixo do flutuante, as boias era dessa altura daí! Uma boia ali, outra aqui, eu metia a canoa por debaixo do soalho, aí ficava $[\ldots] "$.

(c) Urbana: Rev. Eletrônica Cent. Interdiscip. Estud. Cid Campinas (SP) V.8, n.2 [13] $\quad$ p.115-146 ISSN 1982-0569 
Do outro lado do Igarapé da Cachoeirinha, na margem dos Educandos, estava o flutuante da família de Edneia Cortezão, que desde 1955, quando seu pai o comprou, sempre fora coberto por folhas de alumínio. Tratava-se de um flutuante de boas proporções, o suficiente para abrigar as sete pessoas da família e as duas empregadas trazidas por Djalma do interior para trabalharem na casa, em cuja frente também funcionava o comércio da família.

Por intermédio das lembranças de Edneia, também pudemos entrar no espaçoso flutuante da família Cortezão, situado em uma das melhores áreas do litoral de Manaus, de frente para o Porto de Catraias no Igarapé dos Educandos:

[...] Era três quartos, o comércio na frente e cozinha, eu lembro dos compartimentos dele, é na frente era comércio, no meio entrava para a sala, uma salinha né, e já entrava nos quartos, entrava na cozinha, tudo entrando pela frente ou pelas laterais, tinha porta nas laterais também, coberta di alumínio, lembro $[\ldots]$.

Pouco depois da boca do Igarapé dos Educandos, estava o flutuante de Mário dos Santos, que deixara junto com a mãe, em 1954, as beiradas do Centro para morar num flutuante ancorado ao quintal do irmão João Cesário na beira dos Educandos. O flutuante de Mário também era coberto com as caras folhas de alumínio, mas, diferente da espaçosa moradia de Sebastião e da residência/comércio de Edneia, a casa de Mário, como ele próprio descreveu, era "[...] um flutuantezinho pequeno $[\ldots]$ " parecendo muito mais com os flutuantes de Vivaldo Correa e Francisca Malta na "Amazonense".

João Cesário, desde a infância no Lago do Limão, sempre foi um hábil manipulador dos mais variados tipos de madeiras próprias para construção de barcos, conhecedor de suas propriedades (especialmente sua capacidade de flutuação), suportes, resistência, pesos e medidas. Por isso, entre os entrevistados, João foi o que mais me forneceu detalhes dessa peculiar construção cabocla amazonense. Ciência advinda e maturada a partir de um saber internalizado que João foi pacientemente destrinchando, dando formas à casa flutuante abaixo:

[...] arranjavam aquelas boias de $A c ̧ a c u$, açacuzeiro, sabe o que é? É uma árvore muito grossa, que engrossa muito e ela dentro da água ela fica, a água conserva ela; aí juntava 5 ou 6 açacuzeiros daqueles que eles só tiravam mesmo a raiz e os galho, ficava aquele caule da madeira inteira ne, comprimento de 20 a 25 metros. Às vezes juntavam 4 a 5 toros de madeira daquela de $A c ̧ a c u$, botavam um travejano em cima, cada prego desse tamanho (abertura de suas mãos de $+-30 \mathrm{~cm}$ ) feito de vergalhão pra pregar os ligamento em cima dele, daí levantava as casas.

Pelo que se depreende das narrativas orais, construir flutuantes, diferentemente do que repõe um senso comum e do historicamente suscitado, não tinha nada de instintivo e desorganizado. Pelo contrário, como enfatizou outro narrador, o atual arquiteto Bosco 
Chamma, trata-se de uma "[...] engenharia rústica e quem tem essa tecnologia é o caboclo né [...]". Assim, essas moradias são expressões de uma cultura material que devem obedecer a conhecimentos e técnicas precisas, condição sine qua non para sua durabilidade, segurança e adequação às demandas da vida sobre as águas.

Uma observação mais refinada nos fornecerá ainda maiores explicações e particularidades da construção dessas casas. Um fator comum, na fala dos entrevistados, é a madeira, todo flutuante, enfatizou Creuza de Andrade, "era de madeira, num tinha flutuante de (alvenaria) num podia fazer diferente", ou, dissecando mais sua fala, não podia escapar do que era ensinado pela "tecnologia cabocla", do que prescrevia uma antiga cultura material própria do lugar.

Nessa cultura estava inscrito que o maior custo da alvenaria encareceria a obra, e que o maior peso de pedras e tijolos impossibilitaria a flutuação das casas, cuja estabilidade era conseguida justamente pelo emprego de materiais leves como a madeira e a palha, por uma altura menor e por um maior alargamento nos pisos. Custos, materiais e medidas que também se encontravam gravados nas linhas dessa cultura material delineada, agora, nos traços do desenho abaixo, de Moacir Andrade:

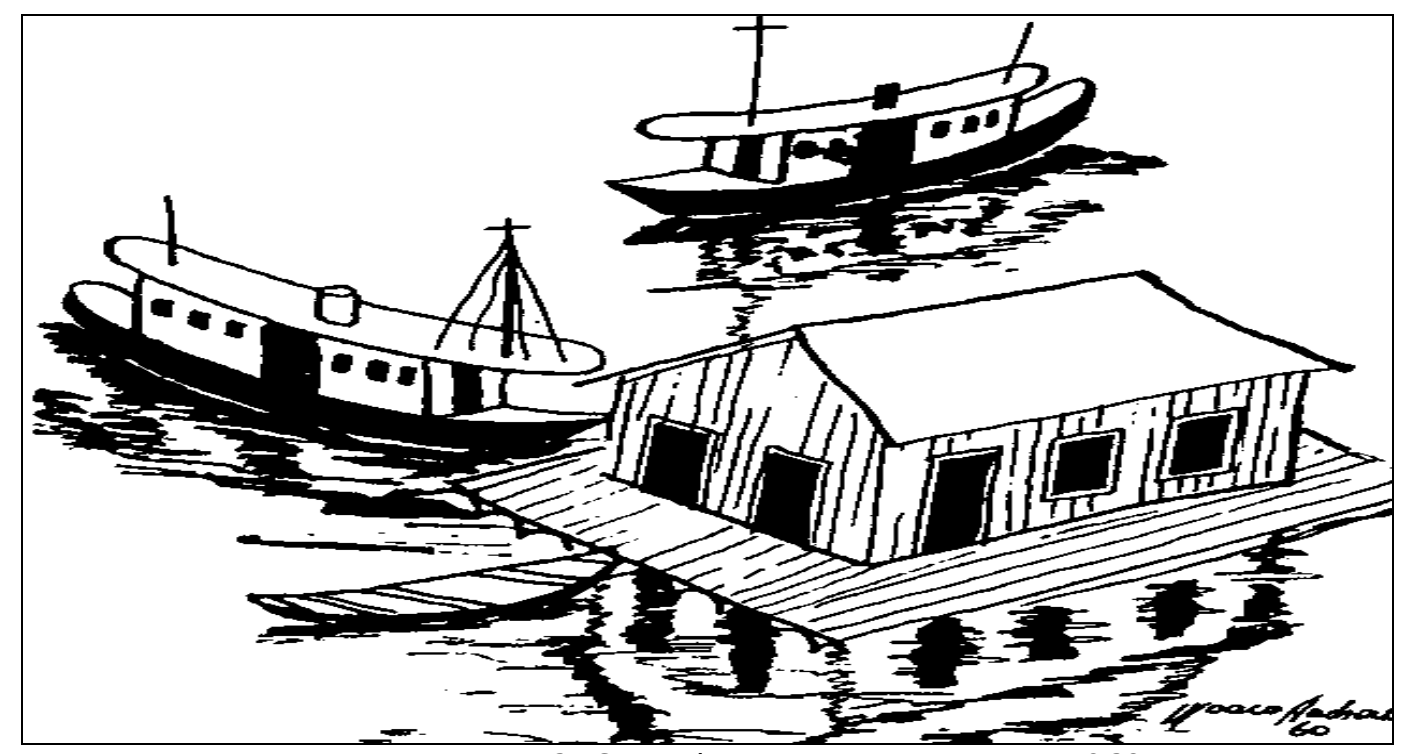

Figura 6: Casa Flutuante no Rio Negro, 1960.

Fonte: (Andrade, 1985, p.180).

O desenho a nanquim sinaliza as divisões internas (três portas e duas janelas), comum a toda casa, dando mostras de um apurado saber/fazer, cujas técnicas de construção envolviam, ao mesmo tempo, detalhes de compartimentação e organização. As duas portas da frente e na lateral indicam que o flutuante de Andrade possivelmente era uma casa de comércio.

O autor, além de sensível talento, usou da memória de antigo morador das ribeiras de Manaus para tecer as linhas da casa que conclui ressaltando a estabilidade: "Os proprietários

(c) Urbana: Rev. Eletrônica Cent. Interdiscip. Estud. Cid Campinas (SP) V.8, n.2 [13] $\quad$ p.115-146 ISSN 1982-0569 
das casas flutuantes, tinham o cuidado especial de somente aplicarem material leve na sua construção, para obterem o máximo de flutuação e consequente mais carga que depositavam sempre num ponto médio da casa para a permanência do equilíbrio" (ANDRADE, 1985, p. 181).

No entanto, não se deve confundir leveza com fragilidade e muito menos generalizar os materiais empregados na construção de flutuantes. Não era qualquer madeira ou palha que poderiam ser utilizadas, sendo imprescindível um saber/escolher dominado apenas pelos moradores do lugar, sobretudo ribeirinhos.

Andrade sublinhou que as madeiras mais utilizadas eram as chamadas madeiras moles, fartamente encontradas nos terrenos de várzeas, de pouca densidade, o que ajudava na estabilidade, quase sem coloração, (conhecidas como madeiras brancas) e de pouco odor para não chamar a atenção de animais, sobretudo mosquitos, comuns nas várzeas (Ibid., p. 179180).

O tipo de madeira mais utilizado como boias era o Açacu que Batista (1976, p. 106108) classificou como uma "madeira leve". Para João Cesário, o Açacu era, sobretudo, uma madeira muito grossa e tinha a importante propriedade de não apodrecer na água, pelo contrário, ela a conservava e ainda "engrossava" sua largura, aumentando sua capacidade de flutuação. Flutuação, resistência e estabilidade, características imprescindíveis para o êxito na construção de casas sobre as águas.

Segundo Sebastião Garcia, não deveria ser muito difícil para os moradores conseguirem as toras de $A c ̧ a c u$. Oficialmente, dentro da "cidade flutuante" existiam duas grandes serrarias, que depois de beneficiarem a parte da madeira que lhes interessava, soltavam os grandes e pesados troncos pelas águas do litoral. "[...] soltava aí por conta de quem quisesse [...]", explicou Sebastião, e muitos os queriam, como o seu próprio vizinho, que com esse material levantou seu "[...] flutuantão (de) 75 palmo!" no Igarapé da Cachoeirinha.

Dependendo do tamanho da casa, juntavam de 4 a 8 boias e, como ensinou João Cesário, "botava um travejano em cima": conjunto de traves onde eram pregadas as madeiras/boias, formando o assoalho que, via de regra, era oriunda do Louro Vermelho, madeira moderadamente pesada, usada ainda nas paredes externas e internas. 0 prolongamento do assoalho ajudava na estabilidade e protegia a casa de possíveis choques com coisas flutuando à deriva, daí o emprego de madeiras pesadas, como a Acariquara, Sucupira e Maçaranduba, com as quais também se cercavam, sobretudo nos flutuantes de comércio, as varandas, outro forte parapeito destinado tanto à proteção como às ancoragens das embarcações.

Além de lugares de comércio, as sacadas eram ainda espaços de socialização nos quais os vizinhos se debruçavam para colocar a conversa em dia e se inteirar das novidades, penduravam a rede para a sesta, como Vivaldo, ou, segue ele: "[...] à noite você se sentava no passeio do flutuante com sua família, com a namorada né $[\ldots]^{\prime \prime}$ e ali ficavam conversando 
noite adentro. Eram ainda locais propícios para se lavar e secar as roupas em varais improvisados, como fazia a lavadeira Francisca da Silva: "[...] agente tinha corda [...] era tudo ali, tudo na varanda, na corda de náilon [...] pra não voar, pra não cair n'água [...]". Para as crianças, as varandas se revestiam de lembranças lúdicas, território de brincadeiras. "[...] Ah! Mas flutuante tinha varanda, agente brincava $[\ldots] "$, narrou Edneia.

Das varandas, chegamos à cobertura dos flutuantes, onde encontramos os caibros de sustentação provenientes da Andiroba, conhecida na região por seu odor característico e que se acreditava afugentar os mosquitos como as carapanãs, comuns em zonas ribeirinhas, especialmente no período da vazante.

No flutuante de Francisca Malta parecia funcionar muito bem, ela não entendia o porquê, "[...] eu acho que ali sempre era correnteza [...]" do rio, supôs, ou talvez as propriedades repelentes da Andiroba ajudassem nas noites tranquilas da família. O certo, segundo ela, era que "não tinha carapanã" algum no seu flutuante. Bem diferente da casa do vizinho Vivaldo Correa, onde nem a queima do querosene à noite, para iluminar o flutuante, afugentava a mosquitada: "[...] mosquito todo tempo tinha, todo tempo [...]", nos disse ele.

Sobre os caibros de sustentação eram dispostas as coberturas das casas, à base de palha, comum nas décadas iniciais dos flutuantes em Manaus, entre 1920 e 1950. As tradicionais palhas, ao que informa Andrade (1985, p. 180), eram originárias do Buçu, fibra extremamente leve e resistente e que se adaptavam facilmente às moradias e necessidades dos moradores acostumados ao uso da palha como cobertura e como paredes de suas palafitas, barracas, tapiris e flutuantes.

Toda a estrutura levantada (piso, varanda, paredes e cobertura) sobre as toras de madeira, segundo Mário dos Santos e Francisco da Silva, fazia as boias de Açacu afundarem cerca de 1 metro, deixando-os a 50 centímetros da água. Pode parecer pouco e arriscado, mas para Mário, "era tranquilo, os toros de Açacu eram grandes" e, para Francisco, a robustez das boias garantia a segurança e a estabilidade das casas: "[...] a boia era forte! Era forte! Entendeu? E ela não arriava aí butava, podia butar mercadoria, peso, essas coisa [...]".

Apesar das diferenças descritas nas narrativas (tamanho, cobertura, etc.), padrões, sobretudo no tocante à estabilidade, deveriam ser obedecidos por quem decidisse morar nas águas. Na fotografia abaixo, vê-se em primeiro plano um exemplo da estrutura de uma casa flutuante e, ao fundo, como ela provavelmente ficará depois de terminada a construção: 


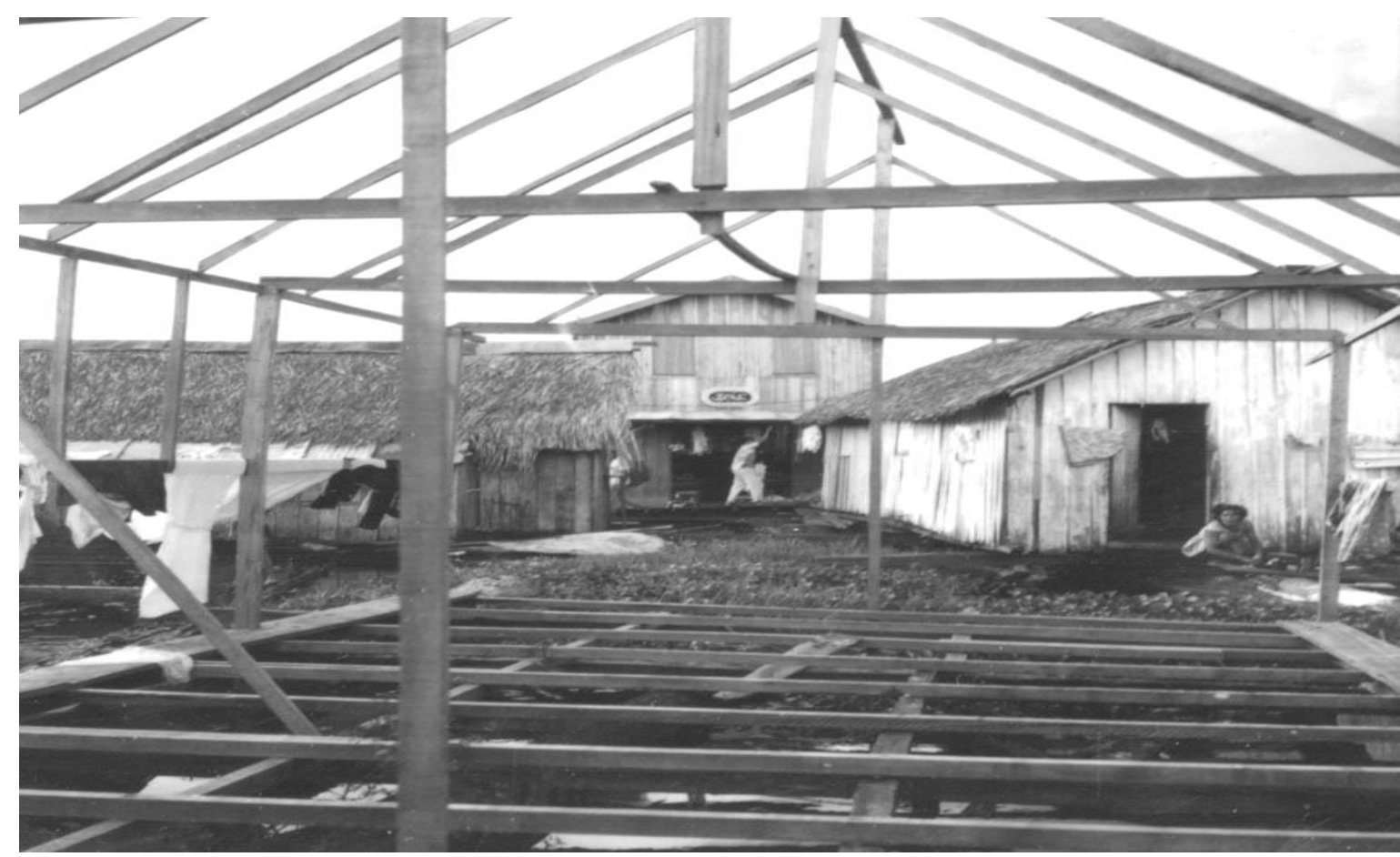

Figura 7: Armação de Casa Flutuante.

Fonte: www.biblioteca.ibge.gov.br/colecaodigitalfotografia.

$\mathrm{Na}$ imagem não podemos observar as boias, que por conta da estrutura sustentada, como informaram Francisco e Mario, devem ter afundado "um metro" na água. Sobre as boias, vemos os "travejanos" onde se pregará o piso e se erguerá a armação das paredes laterais, que a julgar pela porta da frente, única, e da janela à esquerda, trata-se de um flutuante de moradia, diferente do seu vizinho aos fundos: casa de dois andares com nome, ampla porta de entrada com mercadorias expostas.

Não é possível ver se a "cumeeira" do flutuante será de palha ou zinco. Por outro lado, a dos seus vizinhos é de palha. Sua estrutura, por enquanto, estava servindo mesmo como varal para as roupas da moradora agachada e ocupada em seus afazeres, que parou por um instante para captar a lente do fotógrafo.

Enfim, um conjunto de materiais assume significados próprios na cultura do lugar: a madeira leve e resistente como o $A c ̧ a c u$, que ainda "[...] engrossava dentro da água [...]", para as boias; a pesada Acariquara para os parapeitos/varandas; as "moderadamente pesadas" Louro Vermelho para o assoalho e paredes laterais; a Andiroba, com suas propriedades repelentes, compondo os caibros de sustentação das coberturas de palha Buçu ou zinco que viria em seguida.

Se a madeira das boias e armações se manteve como norma para a construção dos flutuantes, sua cobertura, no entanto, com o passar dos anos, pôde variar. O uso do zinco inaugurou uma concorrência às palhas, que ainda assim permaneceram em maior relevo do teto das moradias flutuantes, sobretudo as de baixo custo.

Gradual transformação ocorrida graças à maior e mais diversificada atividade comercial sobre as águas, permitindo o surgimento de uma destacada classe de comerciantes que 
puderam diferenciar suas residências-comércio, não apenas pela arquitetura (casas maiores, de dois andares, pintadas), mas ainda pelas caras coberturas de liga metálica que reluziam ao longe, diversificando, finalmente, as formas da "cidade flutuante".

O zinco, por sua vez, poderia ser mais resistente, duradouro, mas, por conta de seu maior peso, demandava algumas alterações na estrutura da moradia flutuante. Mário dos Santos disse que a cobertura com esse material exigia o "[...] levantamento um pouco mais do pé direito do flutuante $[\ldots]^{\prime \prime}$, caso contrário, a estabilidade da casa ficaria comprometida.

O flutuante de Mário era coberto com zinco porque, segundo ele, a palha "[...] dava muita goteira $[\ldots]^{\prime \prime}$ e isso, numa região de fortes chuvas sazonais, era um grande problema. A ressalva de João Cesário à palha era o maior risco de incêndio que poderia consumir as casas e a vida dos moradores, agravando-se ainda mais, segundo João, "[...] porque bombeiro não tinha condições de ir lá $[\ldots]$ ", quase no meio do Rio Negro que a "cidade flutuante", nos anos de 1960 , alcançava.

Ainda assim, Mário não esqueceu a grande desvantagem do zinco em relação à palha, "[...] esquentava pra caramba né!", ainda mais em se tratando de flutuante, casa de menor altura, cujo interior abafava, sobretudo ao longo dos cinco meses do forte verão amazônico.

Questionado em relação às goteiras e aos perigos de incêndio, Vivaldo Correa foi categórico: "[...] não, não, tem problema não [...]". O que parecia contar para ele era a boa construção das casas. Madeiras adequadas e palhas ciosamente fechadas, além de evitar as goteiras, propiciavam moradias bem mais arejadas e equilibradas sobre as águas.

Para Vivaldo Correa, a "cidade flutuante" onde morou desde 1953 era quase toda de palha, poucos, os de "[...] condição financeira boa $[\ldots]$ " podiam cobrir com zinco. Para Sebastião Garcia, coevo a Vivaldo, todavia, as folhas metálicas passaram mesmo a definir as casas flutuantes: "[...] nessa época os flutuantes mesmo, tudo era coberto de alumínio [...]". Regra que, segundo Edneia Cortezão, se consolidaria só nos anos 60: "[...] a maioria era de alumínio e tinham pouco de palha $[\ldots]^{\prime \prime}$.

Em outras narrativas orais, no entanto, preponderou o equilíbrio entre palha e zinco. À mesma época de Edneia, Francisco da Silva contou que na "cidade flutuante", gradativamente foram chegando os "caros alumínios", diferenciando algumas casas como a de Cristóvão, dono do minúsculo quarto coberto de palha que ele alugava para a família de Francisco. A casa flutuante de Cristóvão, porém, enfatizou Francisco, "era diferente", coberta em zinco, espaçosa, "tinha assim dois anda $[\ldots] "$ ".

Os negócios iam muito bem para Cristóvão. Ele vivia apenas dos aluguéis, e não faltavam inquilinos para os seus quartos. Creuza, por exemplo, disse que seu marido não teve nenhuma dificuldade para encontrar casa na "Amazonense": "[...] tinha muito ali pra alugar, tinha demais, demais [...]". Ele acertou os "15 cruzeiros" do aluguel e providenciou a mudança para a "cidade flutuante".

(c) Urbana: Rev. Eletrônica Cent. Interdiscip. Estud. Cid Campinas (SP) V.8, n.2 [13] $\quad$ p.115-146 ISSN 1982-0569 
Francisco da Silva suspeitou de uma tal "sociedade" de comerciantes que seriam construtores de flutuantes que lucrariam com o crescente mercado de aluguéis sobre as águas de Manaus. "[...] Era porque, era assim, porque o pessoal alugavo, fazia, alugava pra morar e assim ia entendeu [...]". Como acontecia em terra, explicou Creuza de Andrade, que não sabia quem era o locador de sua casa, dando a entender que "o pessoal" poderia ser alguma organização ou corporação, cuja atividade comum era o mercado dos aluguéis na "cidade flutuante".

Quando quisemos saber de João Cesário: "quem construía os flutuantes?", ele lembrou, como Vivaldo Correa, primeiro da regra geral: "As pessoas mesmo faziam [...]". Em seguida, porém, João também recordou dos muitos comerciantes enriquecidos que mandavam fazer flutuantes nos interiores para depois rebocá-los para a orla de Manaus, onde poderiam alugálos ou abrir comércio, atividades bastante promissoras, como fez um antigo cliente seu, negociante de juta e borracha, comprador de um flutuante no interior que, segundo ele, "[...] pegava 300 toneladas de peso $[\ldots]^{\prime \prime}$.

Quando Creuza de Andrade qualificou seu flutuante de "vagabundinho", o fez em relação às casas dos vizinhos da frente: "O flutuante dessas pessoas que tinham mais dinheiro era melhor do que as outras casas". Os primeiros, verdadeiras "mansões" aquáticas opostas ao seu "vagabundinho" flutuante:

Era melhor, Deus me livre! Eu não tô dizendo, melhor mesmo do que as outras casas; olha, pelo menos os maiores que [inaudível] moravam na frente, você gostava de vê, era de madeira, mas era, posso dizer, comparado a uma mansão sabe, comparada uma mansão, era muito bom, muito bom mesmo.

Se as boias de $A$ çacu e as madeiras representam um traço comum na construção dos flutuantes, elas estão longe de significar a uniformidade das casas que poderiam ir do "flutuantezinho" de Anísio Pedro no Igarapé da Glória, ao "flutuantão" de Sebastião Garcia no outro lado da cidade, no Igarapé da Cachoeirinha.

Poderiam ser um quarto, "tipo um embriãozinho", como o flutuante de Creuza de Andrade e Francisca da Silva; um quarto, sala e cozinha como de Vivaldo Correa e Francisca Malta; ou de três quartos, sala e cozinha como era o amplo flutuante residência/comércio da família Cortezão.

Poderiam ser cobertos de palhas ou zinco; serem alugados junto à suposta "sociedade" sugerida por Francisco da Silva, ou poderiam ser próprios, construídos pelos moradores como fizeram Vivaldo e João, ou ainda comprados já prontos na "cidade flutuante" como preferiu Elias Malta, marido da entrevistada Francisca Malta.

Outra imagem dessa variedade de formas das casas flutuantes, encontramos em uma reportagem da revista O Cruzeiro, enfocando de um mesmo ângulo, diferentes flutuantes da cidade, que à época da matéria (1963), não paravam de se adensar pela orla urbana de Manaus. Selecionamos duas fotografias unidas em uma mesma imagem:

(c) Urbana: Rev. Eletrônica Cent. Interdiscip. Estud. Cid Campinas (SP) V.8, n.2 [13] $\quad$ p.115-146 ISSN 1982-0569 

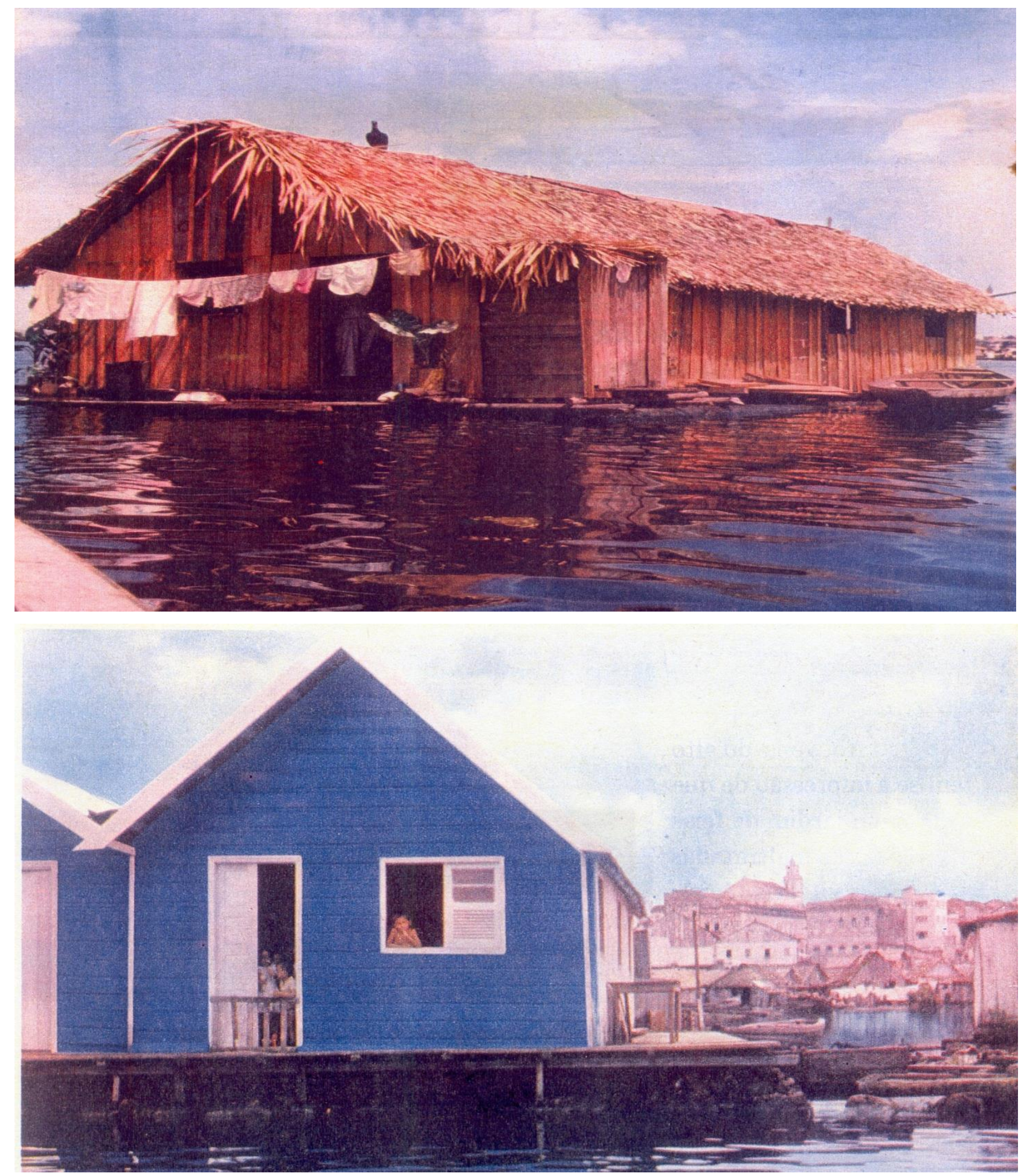

Figura 8: Flutuantes de Manaus no Rio Negro.

Fonte: Revista O Cruzeiro de 08 de Junho de 1963.

A primeira fotografia traz um flutuante de bom tamanho, sem grandes preocupações com a padronização de suas formas e de seus espaços internos, coberto com as tradicionais palhas, desprovido de pintura ou demais ornamentações em suas paredes, sem varanda, tendo como limites, as suas próprias boias. 
Já na segunda fotografia, dois flutuantes indicam outros desenhos para as casas, mais comuns a partir da expansão comercial da "cidade flutuante" nos anos sessenta: as coberturas de zinco, ornamentos como pintura (azul e branco), uma padronização nas formas das casas, uma varanda com portão para proteger as crianças que observam provavelmente o fotógrafo no Rio Negro.

De qualquer maneira, tanto os discursos orais como as imagens propõem uma multiplicidade de formas para a "cidade flutuante" que escapam aos discursos tradicionais nos quais prevalecem a uniformidade de casas minúsculas, frágeis, ordinárias e desorganizadas, meras "barracas de madeira" (SERRA e CRUZ, 1964, p. 37-38), ou, o não menos reducionista, "simples tapiris" de (LENZ et al., 1966, p. 04).

Ao tempo das fotografias acima (1963), a "cidade flutuante" aproximava-se do seu fim, para o qual concorreram, entre outros fatores, justamente as formas de suas casas, denunciadas como anti-higiênicas, feias e ultrapassadas, antíteses das configurações do sano, funcional, belo e moderno pretendidas para a urbe pela nova ordem política, que a partir de 1964 definiu os flutuantes de Manaus como grave problema social e sua completa destruição como solução.

\section{"Olha, a cidade flutuante vai sair todinha, nós vamo ter que se mudar}

\section{daqui"}

Foi o que Creuza de Andrade ouviu do marido logo que chegou, depois de um longo dia de trabalho no restaurante flutuante. Foi ele quem recebeu as pessoas: "[...] eram homens e mulheres que andavam $[\ldots]$ " fazendo perguntas aos moradores, para finalmente comunicá-los que o governo iria extinguir a "cidade flutuante" e um amplo processo de remoção teria início ainda naquele ano de 1964.

Francisco da Silva também não estava em casa naquele momento. Ele andava em meio a seus afazeres no Mercado, mas sua mãe, Francisca da Silva, que lavava roupa no flutuante, estava e foi quem falou com os tais "homens e mulheres" que ela lembra, foram logo inquirindo: "Quantas pessoas que tem aí? Quanto é? Nome? Feminino? Masculino?". Francisca não conseguiu identificar muito bem as tais pessoas. Segundo Francisco, pareciam ser do Exército, talvez da Marinha, quem sabe do Governo?

De qualquer forma ele estava correto: tratava-se dos representantes do governo de Arthur Cezar Ferreira Reis, que em junho de 1964 assumiu em nome da "Revolução" Militar, o governo do estado do Amazonas. Uma das principais metas de seu governo seria a definitiva e completa destruição da "cidade flutuante", que à época tinha mais de uma década de existência.

Assim, entre as "[...] medidas administrativas mais importantes $[\ldots]$ " que o governador projetou para 1965, a "[...] extinção da cidade flutuante, a favela fluvial de Manaus" foi uma das primeiras a ser anunciada "[...] de modo que os que vivem presentemente naquele núcleo

(c) Urbana: Rev. Eletrônica Cent. Interdiscip. Estud. Cid Campinas (SP) V.8, n.2 [13] $\quad$ p.115-146 ISSN 1982-0569 
exótico não se sintam feridos nos seus interesses, ao contrário, se possam sentir aquinhoados de bem estar" (REIS, 1964, p. 10).

Antes, porém, eram necessários alguns dados, observações e levantamentos que dessem a conhecer melhor os flutuantes, permitindo estratégicas informações sobre esse fenômeno social e urbano há tempos em processo pela orla de Manaus. As autoridades não pretendiam atender necessidades e problemas dos flutuantinos, longe disso. As perguntas dos representantes do governo, como nos contaram os entrevistados, pareciam ter como pedra angular a palavra "quanto". Quantificar pessoas e casas era o cerne dessas pesquisas.

Para a "problemática" dos flutuantes, o governador criou comissões específicas, que em apenas dois meses (abril a maio de 1965), chegariam a três. Se o texto da primeira comissão ainda ditava uma "mudança da Cidade Flutuante", nas duas últimas a finalidade dos trabalhos era textualmente: "a extinção dos flutuantes da Cidade de Manaus" (OLIVEIRA (org.), 1965, p.175, 189 e 208).

Outro indicador da pressa das medidas oficiais contra a "cidade flutuante" foi a criação, em junho de 1965, da Companhia de Habitação do Amazonas (COHABAM) para gerenciar a política das habitações e cuja primeira ação foi a construção do Conjunto Costa e Silva, no bairro da Raiz (subúrbio de Manaus), a ocorrer concomitantemente aos "[...] levantamentos das populações a serem transferidas para aquele conjunto [...]" (CADERNOS de Arquitetura Brasileira, 1967/68, p. 72).

O Plano Bienal do governo (1965/1966) previa a construção de 2.000 moradias para aqueles moradores. No entanto, em 31 de dezembro de 1966, apenas 130 casas haviam sido erguidas e duas estavam em execução (REIS, 1967), ou seja, pouco mais de 5\% das 2.500 casas que o próprio Arthur Reis pensou existir na "cidade flutuante" do período. Ou seja, as 130 casas do governo não dariam nem ao menos para os vizinhos de Francisco da Silva nas águas da "Amazonense", onde, segundo calculou, "[...] tinha, mais ou menos, uns 150 habitantes (só) naquela área $[\ldots]^{\prime \prime}$.

Dessa forma, o governo se viu obrigado a abrir outra frente de serviços na forma de mais um conjunto residencial, Flores, a noroeste do Centro e mais distante ainda deste, e que, como Costa e Silva, tinha obras paralisadas e atrasadas. Outra saída, urgente e atabalhoada lançada pelas autoridades foi uma série de loteamentos em bairros recém-abertos, como o Santo Antonio e Glória.

Tanto as casas da COHABAM, quanto os loteamentos não conseguiram representar nem mesmo uma solução paliativa para o abrigo dos moradores removidos. Remoção que, ao passar dos meses, foi assumindo cores de expulsão propriamente dita.

Depois das comissões, das entrevistas, das fichas e das marcações, vieram os prazos das autoridades para os moradores deixarem seus flutuantes. Ordens emitidas pelos três Capitães dos Portos, que entre junho e novembro de 1965, tomaram à frente nas ações de 
destruição da "cidade flutuante" que o governador Arthur Cezar Ferreira Reis procurava acelerar de todas as formas.

Ainda assim, de maio de 1965, quando o Capitão dos Portos Gilberto Ferraz começou a retirar os primeiros flutuantes, até a extinção completa da "cidade flutuante", passaram-se quase dois anos. Foi apenas sob o comando de outro capitão, Mário da Costa Paiva que entre 1966 e 1967 destruíram-se os últimos flutuantes da cidade.

A conturbada e desorganizada destruição, na medida em que expulsava os moradores, obrigava-os a continuar expandindo os limites de Manaus, tanto a partir dos loteamentos oficiais em bairros como Santa Luzia, São Jorge, Gloria e Santo Antônio, como a partir da criação de novas ocupações suburbanas, caso do bairro da Compensa (um dos maiores atualmente).

Se a criação da "cidade flutuante" representou uma impactante transformação pela orla central de Manaus, seu desmantelamento, em 1967, não foi menos significativo para o reordenamento da urbe, na medida em que "produziu" milhares de desabrigados. Essas transformações, no entanto, eram toleráveis, posto que longe do Centro de Manaus, ponto de partida de outro projeto de modernização amazonense pretendido por Arthur Cezar Ferreira Reis, cujo carro chefe agora respondia pela Zona Franca de Manaus, o "grande projeto" industrial amazonense.

Para tanto, uma série de transformações em sua principal cidade, Manaus, teriam que ocorrer. Se entre o projeto de Lei Federal 3.173, de 1957, que criara a Zona Franca, e o início do governo de Arthur Reis em 1964 praticamente nada acontecera para a efetivação da Lei, durante os poucos mais de dois anos de sua administração, Manaus sofreria uma impactante intervenção urbana, tendo como um de seus pontos altos a completa destruição da cidade sobre as águas por toda a orla central da capital.

Naquele momento, segundo lembra Vivaldo Correa, o assunto Zona Franca já corria pela cidade. A "[...] a Zona Franca vem aí $[\ldots]$ " era o zunzum mais ouvido. Mas a questão flutuantina, como arrematou Vivaldo, "insistia" em existir: "[...] a Zona Franca só veio mesmo a funcionar depois que terminasse a cidade flutuante" que se mostrava na contramão do novo tempo de progresso e civilização do "Novo Amazonas", (política propagandística de Arthur Reis), por conta de suas formas, madeira e palha, base de uma estética urbana popular tradicionalmente condenada pelos poderes públicos.

Ainda mais 2.500 "barracos" flutuantes boiando na frente da cidade, portão de entrada por onde se deveria chegar ao Porto e ao "Novo Amazonas". A "cidade flutuante", com suas tábuas, seus caibros, suas palhas de buçu, seus imensos toros de Açacu serpenteando na forma de vielas e becos suspensos sobre a água representava o velho, o bárbaro, o antiestético que enfearia o rosto da "cidade sorriso", tal como batizada por uma historiografia elitista e saudosista.

(c) Urbana: Rev. Eletrônica Cent. Interdiscip. Estud. Cid Campinas (SP) V.8, n.2 [13] p.115-146 ISSN 1982-0569 
Por outro lado, a "cidade flutuante", as vésperas do fim, tinha se tornado um dos ícones do Amazonas, sendo alvo das reportagens de revistas nacionais e internacionais e locação cinematográfica, ${ }^{7}$ todos atraídos pelas imagens do exótico com as quais, habitualmente, se pinta a Amazônia. Nesse cenário de cores midiáticas, a cidade sobre as águas também passara a ser uma poderosa paisagem, atraindo olhares de uma indústria turística em forte marcha no período.

A título de exemplo, recuperemos apenas as manchetes onde imperam conotações como: "A cidade flutuante de Manaus é uma espécie de Veneza selvagem e tropical [...]" (MANCHETE, 1963); ou os seus confrades de "O Cruzeiro" (1963) com os emblemáticos: "Favela Veneziana" e/ou "Veneza brasileira", ou ainda a revista suíça "Amazonie" (1962) com outra chamada hiperbólica: a "petite Venezia".8

De qualquer forma, essa notoriedade não interessava ao "Novo Amazonas" da Zona Franca, pois tinha como "ator" principal a "cidade flutuante" que começou a ser ferrenhamente combatida a parir de 1964. Os turistas, segundo os anúncios do novo governo, deveriam vir ao Amazonas por conta do seu passado gravado na arquitetura art noveau da "Manaus da borracha" e pelo presente do "turismo industrial", para se fartarem nas compras dos modernos artigos eletroeletrônicos produzidos pela Zona Franca (CADERNOS de Arquitetura Brasileira, $1967 / 68$, p. 128).

Entre a "Manaus da borracha" e a cidade Zona Franca, no tempo em que se destacou a "cidade flutuante", nada deveria permanecer. A própria COHABAM fazia parte de um projeto mais amplo, indo além do planejamento de conjuntos, algo paralisado tão logo a "cidade flutuante" acabou. Sua principal missão era mesmo reorganizar a cidade, dotando-a de uma infraestrutura urbana progressista condizente a de uma capital em vias de inaugurar sua Zona Franca Industrial, patrocinando, por exemplo, a vinda para Manaus de alguns arquitetos cariocas, cuja ação inicial foi, em 1965, o Plano Diretor de Manaus, o primeiro de sua história. ${ }^{9}$

Sob a batuta desses profissionais, mesmo a arquitetura art noveau da "Manaus da borracha" foi rediscutida à luz de construções que fossem mais ao encontro das particularidades ecológicas da cidade, ou como declara o arquiteto Oiticica (1967/68, p. 74), "[...] estivesse de acordo com o clima e que utilizasse materiais da região".

A "cidade flutuante", no entanto, não foi reconhecida como uma peculiaridade da região. Ainda que se adequasse às características ecológicas do lugar, ela era vista como expoente máximo de desorganização urbana e promiscuidade social e sanitária:

\footnotetext{
7 Filme "O Homem do Rio" (1963) de Philippe de Broca, estrelado por Jean Paul Belmondo.

8 Em 1962 a "cidade flutuante" foi noticiada pela National Geographic e, em 1963, pela revista portuguesa Seara Nova.

${ }_{9} \mathrm{O}$ historiador Luiz de Miranda Corrêa lista os arquitetos que vieram sob o patrocínio do governo estadual: Severiano Porto, Luiz Carlos Antony, Fernando Pereira da Cunha, Leon Shastri, Cezar Oiticica e Ivan Pimentel que "[...] formam o núcleo original da reforma em processamento da arquitetura amazonense" (CORREA, 1969, p. 58-59).
}

(c) Urbana: Rev. Eletrônica Cent. Interdiscip. Estud. Cid Campinas (SP) V.8, n.2 [13] $\quad$ p.115-146 ISSN 1982-0569 
A urbanização do caboclo é a sua tragédia, tragédia esta que se reflete, principalmente, em sua habitação. Estes agrupamentos tiveram seu ponto culminante na já famosa cidade flutuante do porto de Manaus. As condições sanitárias precaríssimas e a promiscuidade geram toda sorte de contágios e o caboclo desfigura-se física e psiquicamente (Ibid.,1967/68, p. 77).

Mais do que construções, plantas e projetos, a arquitetura do "Novo Amazonas" representava uma assinatura de poder na qual a "cidade flutuante" não deveria ter nenhuma linha. Ordem instalada na cidade pelo governo de Arthur Cezar Ferreira Reis que, por intermédio de um regime de exceção e compartilhando as perspectivas de modernidade em voga, passou a ditar o rumo e o ritmo de expansão de Manaus, interferindo em modos de vida próprios do lugar, condenando tudo que se mostrasse contrário ao pensamento do "Novo", moderno e civilizado. A "cidade flutuante", nesse sentido, foi a expressão máxima dessa censura.

\section{Referências}

Entrevistas

Anísio Pedro da Silva - nascimento: 14.03.1937; local: Rio Ituxi (Lábrea-AM); profissão: aposentado; relação com a "cidade flutuante": morador; data da entrevista: 13.01.2008.

Creuza Rodrigues de Andrade - nascimento: 26.10.1940; local: Rio Jaú-AM; profissão: aposentada e vendedora de churrasco; relação com a "cidade flutuante": moradora de 1962 a 1967; datas das entrevistas: 15.03 e 12.09.2008 e 09.12.2009.

Edneia Roque Cortezão - nascimento: 19.01.1960; local: Manaus-AM; profissão: funcionaria do IBGE; relação com a "cidade flutuante": moradora de 1960 a 1967; data da entrevista: 18.02.2008.

Francisca da Silva Malta - nascimento: 14.03.1937; local: Canindé-CE; profissão: do lar; relação com a "cidade flutuante": moradora de 1958 a 1966; datas das entrevistas: 25.01 e 15.03.2006, 06.03 e 25.09.2008 e 21.11.2009.

Francisca Pereira da Silva - nascimento: 20.09.1913; local: Coari-AM; profissão: do lar; relação com a "cidade flutuante": moradora de 1963 a 1966; datas das entrevistas: 15.01 e 23.09.2008.

Francisco Pereira da Silva - nascimento: 07.09.1949; local: Coari-AM; profissão: vendedor ambulante; relação com a "cidade flutuante": morador de 1963 a 1966; datas das entrevistas: 15.01 e 23.09.2008.

João Bosco Chamma - nascimento: 15.05.1954; local: Manaus-AM; profissão: arquiteto; relação com a "cidade flutuante": brincava e pescava no local; data da entrevista: 28.07.2005. João Cesário da Silva - nascimento: 08.09.1931; local: Manaus-AM; profissão: construtor naval (aposentado); relação com a "cidade flutuante": vizinho; datas das entrevistas: 17.06.2005, 27.09.2008 e 29.11.2009. 
J.M. - nascimento: 22.07.1935; local: Manaus-AM; profissão: comerciante no Mercado Público desde 1948; relação com a "cidade flutuante": fazia negócios com esta; datas das entrevistas: 03.08.2005, 18.10.2008 e 19.11.2009.

Maria do Nascimento Borél - nascimento: 1918; local: Janauacá-AM; profissão: costureira; relação com a "cidade flutuante": teve suas terras ocupadas em 1968 por ex-moradores; data da entrevista: 15.01.2008.

Mario dos Santos - nascimento: 18.12.1942; local: Manaquiri-AM; profissão: vendedor de café em canoa; relação com a "cidade flutuante": morador de 1954 a 1959; data da entrevista: 17.06.2005.

Renato Chamma - nascimento: 29.12.1930; local: Manaus-AM; profissão: comerciante; relação com a "cidade flutuante": vizinho; datas das entrevistas: 03.08.2005, 06.03.2008 e 19.11.2009.

Sebastião de Souza Garcia - nascimento: 10.11.1938; local: Manaquiri-AM; profissão: feirante desde 1953; relação com a "cidade flutuante": morador de 1953 a 1958; datas das entrevistas: $12.02 .2006,26.01,06.03$ e 18.10.2008 e 20.11.2009.

Vivaldo Correa Lima - nascimento: 06.09.1935; local: Manaquiri-AM; profissão: Policial Militar, Cabo Reformado; relação com a "cidade flutuante": morador de 1949 a 1967; datas das entrevistas: 25.01.2006, 06.03 e 01.10.2008 e 21.11.2009.

\section{Bibliografia}

Amazonas. Cadernos de Arquitetura Brasileira, n. ${ }^{\circ}$ 1, 1967/68.

ANDRADE, Moacir. Manaus: ruas, fachadas e varandas. Manaus: Humberto Calderaro, 1985.

ARANTES, Antonio Augusto. Paisagens Paulistanas: transformações do espaço público. Campinas: UNICAMP, 2000.

ARAÚJO, André de. Introdução á Sociologia da Amazônia. Manaus: Valer, 2003.

BATISTA, Djalma. O complexo da Amazônia: análise do processo de desenvolvimento. Rio de Janeiro: Conquista, 1976.

BENCHIMOL, Samuel. Amazônia: um pouco - antes e além - depois. Manaus: Umberto Calderaro, 1977.

Cidade de Manaus. Revista Codeama. Manaus: Governo do Estado do Amazonas, n. 13, jun. 1966.

CORRÊA, Luiz de Miranda. Roteiro histórico e sentimental da cidade do Rio Negro. Manaus: Artenova Ltda., 1969.

COLEÇÃO DIGITAL DE FOTOGRAFIAS. In: IBGE. Disponível em http//www.biblioteca.ibge.gov.br/colecaodigitalfotografia. Acesso em jun. 2010.

INTERVENTORIA FEDERAL. O Amazonas em números. Série Amazoniana, Folhetos Raros. Seção de Obras da Imprensa Pública. Manaus, 2002.

LEDRUT, Raymond. Sociologia Urbana. Rio de Janeiro: Forense, 1971.

(c) Urbana: Rev. Eletrônica Cent. Interdiscip. Estud. Cid Campinas (SP) V.8, n.2 [13] $\quad$ p.115-146 ISSN 1982-0569 
LEFEBVRE, Henri. De lo Rural a lo Urbano. Barcelona: Gráficas Román S.A., 1973.

LENZ, Matias Martinho et al. Os Flutuantes de Manaus. In: Revista da CODEAMA, n. ${ }^{2}$, Junho de 1966 , p. 02-106.

MOURA, Rosa e ULTRAMARI, Clóvis. O que é periferia urbana. São Paulo: Brasiliense, 1996.

MUNFORD, Lewis. A cidade na história, suas origens, transformações e perspectivas. São Paulo: Martins Fontes, 1998.

Observações geográficas na Amazônia. Revista Brasileira de Geografia, Rio de Janeiro, IBGE, n. ${ }^{\circ}$ 3, jul./set. 1949.

OLIVEIRA, José Aldemir de. Manaus de 1920-1967: a cidade doce e dura em excesso. Manaus: Valer/Governo do Estado do Amazonas/EDUA, 2003.

REIS, Arthur Cezar Ferreira. Seis meses de administração. Manaus, 1964.

Um ano de Governo. Manaus, 1965.

Como governei o Amazonas. Manaus, 1967.

REVISTA AMAZONIE. Suíça, 1962.

REVISTA MANCHETE. Rio de Janeiro: Editora Bloch, n. 594, 07 set. 1963.

REVISTA O CRUZEIRO. Rio de Janeiro: Diários Associados, 08 jun. 1963.

REVISTA SEARA NOVA. Lisboa: Julião Quintinha, n. 1409, mar. 1963.

RONCAYOLO, Marcel. Cidade. Lisboa: Imprensa Nacional, 1986.

SALAZAR, João Pinheiro. O Abrigo dos Deserdados. Dissertação de Mestrado em História. São Paulo: Universidade de São Paulo, 1985.

SANTOS, Milton. Espaço e Sociedade: ensaios. Petrópolis: Vozes, 1982.

A Natureza do Espaço: técnica e tempo, razão e emoção. $4^{a}$ ed. São Paulo: Editora da USP, 2006.

SERRA, Celso L. Rocha e CRUZ, Wilson R. da. Aspectos econômicos e sociais da Cidade Flutuante. Manaus: Gráfica Amazonas, 1964.

WILLIAMS, Raymond. Marxismo e Literatura. Rio de Janeiro: Zahar, 1979.

. O Campo e a Cidade: na História e na Literatura. São Paulo: Companhia das Letras, 1989.

(c) Urbana: Rev. Eletrônica Cent. Interdiscip. Estud. Cid Campinas (SP) V.8, n.2 [13] $\quad$ p.115-146 ISSN $1982-0569$ 